\title{
Turbidity current activity along the flanks of a volcanic edifice: The mafate volcaniclastic complex, La Réunion Island, Indian Ocean
}

\author{
Mazuel Aude ${ }^{1,}$, Sisavath Emmanuelle ${ }^{2}$, Babonneau Nathalie ${ }^{1}$, Jorry Stephan ${ }^{3}$, Bachèlery Patrick ${ }^{4}$, \\ Delacourt Christophe ${ }^{1}$
}

${ }^{1}$ Université de Brest, IUEM, UMR CNRS 6538, Domaines Océaniques, Place Nicolas Copernic, 29280 Plouzané, Franc

${ }^{2}$ Fugro GeoConsulting SA, 39 rue des Peupliers, 92752 Nanterre, France

${ }^{3}$ IFREMER, Carnot Edrome, Unité Géosciences Marines, BP70, 29280 Plouzané, France

${ }^{4}$ Laboratoire Magmas et Volcans, UMR CNRS-IRD 6524, Observatoire de Physique du Globe de

Clermont-Ferrand, Université Blaise Pascal, 5, rue Kessler, 63038 Clermont-Ferrand, France

* Corresponding author : Aude Mazuel, Tel.: + 332294988 94; fax: + 332984986 09. ;

email address : aude.mazuel@hotmail.fr

\begin{abstract}
:
Recent marine geophysical surveys reveal the existence of well-developed volcaniclastic deep-sea fans around La Réunion Island, Indian Ocean. The Mafate turbidite complex, located in the northwestern part of the island, is a large sedimentary system formed by two coalescent-like volcaniclastic deep-sea fans: the Mafate fan and the Saint-Denis fan. They are both connected to terrestrial rivers supplying sediment produced by erosion on the island, particularly during austral summer cyclonic floods. Through the integration of marine geophysical data (including bathymetry, backscatter multibeam sounder images, TOBI side-scan sonar images and seismic reflection profiles) and piston cores, a submarine morphosedimentary map of the surface architecture of the Mafate and Saint-Denis turbidite systems has been established. The systems are divided in three main domains: deep canyons in the proximal area, a channel network in the medial area, and distal depositional lobes on the abyssal sea floor. Two large sediment wave fields also formed as a result of the volcaniclastic turbidity currents. Three piston cores collected along the Mafate complex provide information on the sedimentary processes in this area over the last $25 \mathrm{ka}$. The record of turbidite events in these cores is interpreted in terms of volcanic and climatic changes that could have controlled the sediment transfer to the deep ocean.
\end{abstract}




\section{Highlights}

We present the first description of the Mafate-Saint-Denis turbidite complex. Cores offer a record of the Mafate turbidite system activity over the last $25 \mathrm{ka}$. Turbidite activity occurs during a period dominated by erosional processes on land. Two sediment wave fields develop thanks to sandy supplies from turbidity currents.

Keywords: Deep-sea fan, turbidite, volcaniclastic, land-to-sea transfer, La Réunion Island, Late Quaternary

\section{Introduction}

Previous studies interpreting gravity flows and mass movements affecting the submarine slopes of volcanic islands suggest that they have a major influence on the dismantling and enlarging of these islands. Examples include Stromboli Island (Kokelaar and Romagnoli, 1995; Romagnoli et al., 2009; Casalbore et al., 2010), Hawaii Islands (Garcia and Hull, 1994; Moore et al., 1994; Garcia, 1996), Lesser Antilles (Deplus et al., 2001; Boudon et al., 2007), Canary Islands (Schmincke and Sumita, 1998; Krastel et al., 2001, Acosta et al., 2003) and La Réunion Island (Ollier 
et al., 1998; Oehler et al., 2008; Lenat et al., 2009a; Le Friant et al., 2011; Sisavath et al., 2011; Saint-Ange et al., 2013). The occurrence of these gravity processes on land and off shore and the volume of material involved, depend on numerous parameters such as volcanic activity, lithology and alteration, sediment nature and supply, local morphology (slopes) and climate, amongst others.

The characterization of these submarine gravity processes is necessary to understand the evolution of volcaniclastic sedimentary systems over time and their role in the building of the submarine component of ocean-rooted volcanoes. Despite the growing amount of work on the submarine slopes of volcanoes in recent years (Casalbore et al., 2011; Lebas et al., 2011; Romagnoli et al., 2013; Denlinger and Morgan, 2014; Hunt et al., 2014, 2015), we still know little about the mechanisms involved, in particular the relationships between flank instabilities (slumps, landslides, debris avalanches) affecting large portions of the volcanic edifices, and detrital supplies to the abyssal plain. In addition to mass-wasting processes that affect submarine volcanic slopes, turbidite deposits are of strong interest as they record the transfer of sediments from the coastline to the surrounding deep sedimentary basins (Reading and Richards, 1994; Weaver et al., 2000).

From 2006 to 2011, several surveys were conducted offshore La Réunion Island, acquiring a large dataset including bathymetry, backscatter images, TOBI side-scan sonar images, seismic reflection profiles and piston cores from the submarine flanks of the volcanic edifice to the surrounding oceanic plate. These studies have revealed the existence of five volcaniclastic deep-sea fans around the island (Figs. 1, 2). The Cilaos deep-sea fan, the largest of them, has been widely studied (Saint-Ange, 2009; Saint-Ange et al., 2011; Sisavath, 2011; Sisavath et al., 2011, 2012), the other four systems remaining poorly documented. 
The present study focuses on the Mafate volcaniclastic turbidite complex located in the northwestern part of the island. This sedimentary complex appeared especially interesting as it is partly fed by the "cirque" of Mafate, one of the most important erosional features of La Réunion Island, known for its high erosion rates (Louvat and Allègre, 1997); and because it presents a peculiar morphology with two coalescentlike fans: the Mafate turbidite system and the Saint-Denis turbidite system (Fig. 2). This paper presents an integrated study of the morphology and the acoustic and seismic facies that characterize the Mafate volcaniclastic turbidite complex. We describe here the nature and organization of the sedimentary units from the canyons to the distal part of the complex, and focus our observations on the interactions between turbidite processes, adjacent mass-wasting deposits and sediment wave fields. Based on sediment records, the activity of the turbidity currents at the edge of the Mafate turbidite system is reconstructed for the period extending from the present to the Last Glacial Maximum. Results of this study are discussed in the light of previous researches that invoke several controlling factors triggering turbidite activity along the flanks of volcanic edifices.

\section{Geology and geomorphology of La Réunion Island}

\subsection{Geology}

La Réunion Island is an active shield-volcano located in the western part of the Indian Ocean, about $750 \mathrm{~km}$ east of Madagascar (Fig. 1). The island is a volcanic edifice formed by the present activity of the hotspot that formed the Deccan Trapps (65 Ma), the Mascarene Plateau (40 Ma), and Mauritius Island (8 Ma) (Duncan et al., 1989). La Réunion Island is built on an isolated block of oceanic crust dated from 
Upper Cretaceous to Paleocene (Oehler et al., 2008; Lénat et al., 2009b), bordered by two fracture zones, the Mauritius Fracture Zone on the eastern and the MahanoroWilshaw Fracture Zone on the western borders (Fig. 2).

The emerged part of La Réunion Island only corresponds to $4 \%$ of the volume of the entire volcanic edifice, which is characterized by a diameter of about $240 \mathrm{~km}$ at its base and rises up to more than $7000 \mathrm{~m}$ above the abyssal plain. The morphology of La Réunion Island is dominated by two large juxtaposed basaltic shield-volcanoes, Piton des Neiges and Piton de la Fournaise (Fig. 2b). The Piton des Neiges (3070 m above sea level) occupies the northwestern part of the island. Its activity started before 2.4 Ma (McDougall, 1971; Quidelleur et al., 2010; Smietana, 2011) and stopped about 22 ka (Delibrias et al., 1986; Salvany et al., 2012). The oldest Piton des Neiges products (before 2.4 Ma up to $0.43 \mathrm{Ma}$ ) are basaltic in composition, dominated by olivine-bearing basalts and olivine-rich oceanites. They have been emplaced during periods of high effusion rate, corresponding to the shield-building stage of the volcano (Bachèlery and Villeneuve, 2013). The activity ended with the emplacement of more alkaline and differentiated products, ranging in composition from alkali basalts to quartz-bearing trachytes (Nativel, 1978; Gillot and Nativel, 1982; Haurie, 1987; Rocher, 1988a, 1988b, 1990; Bret et al., 2003). The inner part of the volcano is deeply incised by valleys and three major depressions called the "cirques" of Mafate, Salazie and Cilaos (Fig. 2). These appear to be formed by both volcanotectonic processes and intense tropical erosion (Oehler et al., 2004; Arnaud, 2005; Salvany et al., 2012). The active volcano of the Piton de la Fournaise is located in the southeastern part of the island. Its morphology is characterized by concentric caldera rims that open eastward to the sea, and three deep valleys cutting its flanks. The volcano mostly produces basaltic lava flows and fountains, with sometimes more 
explosive, phreatic and phreatomagmatic explosions. Its activity is considered to have started about 0.4 - 0.45 Ma (Gillot and Nativel, 1989; Merle et al., 2010). A review of the main structural and volcanological features of Piton de la Fournaise volcano is presented in Lénat et al. (2012), while details on the submarine flanks can be found in Cochonat et al. (1990), Ollier et al. (1998), Lénat et al. (2009), and SaintAnge et al. (2013).

\subsection{Climate and hydrogeology}

La Réunion Island has a subtropical climate with two alternating seasons: a hot and wet austral summer and a dry and cold austral winter. Trade winds from the east induce varied precipitation regimes in time and space; the windward (eastern) side being dominantly wet (more than $5000 \mathrm{~mm} / \mathrm{yr}$ of rain) while drier conditions prevail on the leeward (western) side. Erosion and sediment fluxes from the "cirques" of Mafate, Salazie and Cilaos are mainly driven by heavy rains and recurring tropical cyclones (Robert, 2001).

The heavy rainfall and the volcanic nature of the island induce high erosion rates, estimated to be about 0.47 to $3.34 \mathrm{~m} \mathrm{ka}^{-1}$ (Louvat and Allègre, 1997). Products of erosion are transported seaward by highly concentrated flows throughout a dense hydrological network comprising more than 750 temporal gullies and rivers (only twenty of which are perennial). For the "Rivière des Galets", draining the "cirque" of Mafate (Fig. 2b), the flow rate, during episodic, highly energetic floods, is estimated to be about $2400 \mathrm{~m}^{3} \mathrm{~s}^{-1}$ (Join, 1991; Fevre, 2005) with a suspended sediment load of about $1920 \mathrm{mg} \mathrm{l}^{-1}$ (Louvat and Allègre, 1997). The erosion rates estimated by Louvat and Allègre (1997) are about $925 \pm 280 \mathrm{~mm} \mathrm{ka}^{-1}$. 


\subsection{Submarine flanks}

The MD 32 (1982), FOURNAISE 1 (1984) and FOURNAISE 2 (1988) pioneering surveys around La Réunion Island first revealed the morphology of the submarine flanks of the volcanic edifice (Averous, 1983; Lénat et al., 1989). Since these pioneer works, several studies characterized the structural and volcanological features on the submarine flanks of the volcanoes. Many of them focused on mass-wasting features produced by fast-running debris avalanches and submarine slope instabilities (Lénat and Labazuy, 1990; Ollier et al., 1998; Lénat et al., 2001, 2009a; Oehler et al., 2004). Oehler et al. (2008) listed 47 collapse events whose products are grouped into four main bulges around the island, separated by large submarine canyons. Recently, Le Friant et al. (2011) proposed that the submarine flanks of the Piton des Neiges are mainly affected by slow deformation and spreading, leading to secondary submarine slope instabilities and unconfined turbidity currents. These unconfined turbidity currents are supposed to be a major driver for the development of large sediment waves surrounding the island. In this paper, we use the term "mass-wasting deposit" to describe the chaotic formations found on the submarine flanks of the island (i.e., catastrophic debris avalanches, secondary submarine slope instabilities or structures produced by slower deformation processes), and acting as substrates for later turbidity currents.

Since the results of cruises FOREVER and ERODER 1 in 2006, and ERODER 2 in 2008 were analysed, most of the canyons surrounding the volcanic edifice were interpreted as the upper parts of large turbidite systems linked to the subaerial hydrographic network and more particularly to rivers draining the "cirques" (SaintAnge, 2009). Five main deep-sea fans have been identified and named around La Réunion Island: Mafate, Saint-Denis, Salazie, Saint-Joseph, and Cilaos (Fig. 2). 
The Cilaos deep-sea fan is the largest volcaniclastic turbidite system off La Réunion Island. It is more than $250 \mathrm{~km}$ in length, covers an area of about $15000 \mathrm{~km}^{2}$ and extends up to $4500 \mathrm{~m}$ water depth (Saint-Ange, 2009; Sisavath, 2011; Sisavath et al., 2011). The fan can be divided into proximal and distal parts. The proximal fan is composed of elongated bodies (topographic lobes), whose morphology appears related to the pre-existing seafloor topography, i.e., the presence of high volcanic ridges at the base of the submarine flanks. The sedimentation in this area is characterized by coarse sandy turbidites (Sisavath et al., 2011). The distal fan is characterized by elongated lobes, extending via narrow channels from the proximal fan. Based on study of sediment cores and shallow seismic data collected here, the shallow stratigraphy comprises a succession of fine sandy turbidites covered by a thick clay layer. Interpretation of the stratigraphic data (from cores) during the last climatic cycle, suggests that frequent turbidity currents have coincided with periods of low activity of effusive volcanism and high erosion of the terrestrial drainage network (Sisavath et al., 2012).

\section{Materials and methods}

\subsection{Dataset}

The dataset used in this paper was collected during five oceanographic cruises (Fig. 3): FOREVER (2006) onboard the R/V L'Atalante, ERODER 1 (2006) onboard the NHO Beautemps/Beaupré, ERODER 2 (2008) onboard the R/V Meteor, ERODER 3 (2010) and ERODER 4 (2011) onboard the R/V Marion-Dufresne.

Bathymetry and backscatter sonar images were acquired with EM12 dual multibeam sounder during FOREVER cruise (-90 to $-5602 \mathrm{~m}$ of water depth, frequency $12 \mathrm{kHz}$, 
162 beams with $1.8^{\circ} \times 3.5^{\circ}$ angular resolution, DTM grid at $150 \mathrm{~m}$, backscatter grid at $100 \mathrm{~m}$ ) and with EM120 dual multibeam sounder during ERODER 1 and 2 cruises (91 to $-5717 \mathrm{~m}$ of water depth, frequency $12 \mathrm{kHz}, 192$ beams with $1^{\circ} \times 1^{\circ}$ angular resolution, DTM grids at $50 \mathrm{~m}$, backscatter grids at $25 \mathrm{~m}$ and $20 \mathrm{~m}$ in ERODER 1 and 2 data respectively). High-resolution sonar images (pixel size $3 \times 3 \mathrm{~m}$ ) were acquired during ERODER 3 cruise, using the TOBI deep-towed side-scan from the National Oceanography Centre, Southampton (side-scan sonar frequency $30.37 \mathrm{kHz}$, pulse length $2.8 \mathrm{~ms}$, array length $3 \mathrm{~m}$, output power $600 \mathrm{~W}$ each side, $3 \mathrm{~km}$ range each side, beam pattern $0.8 \times 45^{\circ}$ fan). The submarine surfaces of the Mafate complex range from high reflectivity (black) to low reflectivity (white) (Fig. 2a). Based on Unterseh (1999) and Baltzer et al. (2000) acoustic imagery analysis and interpretations, and as verified through bottom sampling along the Cilaos turbidite system (Sisavath et al., 2011), high reflectivity is related to heterogeneous coarse products (blocks, pebbles, gravels) such as those found on land in rivers, and low reflectivity to fine sand and muddy-sand. The homogeneous grey areas are interpreted to contain hemipelagic sediment. The mass-wasted deposits show speckle patterns (black specks on grey background) due to blocks covered by hemipelagic sediment.

Seismic reflection profiles were acquired around La Réunion Island during the FOREVER cruise using two Gl guns deployed at $6 \mathrm{~m}$ depth with volumes of 45/45 inch $^{3}$ (band pass filter between 10 and $130 \mathrm{~Hz}$ ) and 105/105 inch ${ }^{3}$ (band pass filter between 8 and $90 \mathrm{~Hz}$ ) and a 24 channel streamer from IFREMER (inter-channel 12.5 $\mathrm{m})$. Penetration is up to $1.5 \mathrm{~s}$ TWT (two-way travel time), vertical resolution is $5 \mathrm{~m}$ and horizontal resolution is $25 \mathrm{~m}$. Seven profiles have been interpreted for the study of the two turbidite systems, and two of them are presented in this article. 
Two Küllenberg piston cores (KERO-07 and KERO-20) collected along the Mafate turbidite system during ERODER 2 have been studied (Table 1, Fig. 3). A complementary Calypso core MD11-3342 collected in the distal part of the complex, on the abyssal plain, during the 2011 ERODER 4 cruise has been also taken into consideration (Table 1, Fig. 3).

\subsection{Core processing}

The sediments were described in all three cores KERO-07, KERO-20 and MD113342. XRF measurements were acquired every centimetre for each core (at 10 and $30 \mathrm{kV}$ ) using an Avaatech XRF Core-Scanner. The core physical properties (density, magnetic susceptibility and P-wave velocity) were also measured with a Multi Sensor Core Logger (MSCL). KERO-07 and KERO-20 were sampled for grain-size analysis using a Coulter laser micro-granulometer.

Fifty-nine samples have been collected along core KERO-07 for oxygen isotope analyses. Sediment samples were dried and sieved with water using a $125-\mu \mathrm{m}$ mesh. Small batches of monospecific planktonic foraminifera Globigerinoides ruber were picked, and specimens were heated under vacuum at $375^{\circ} \mathrm{C}$ for $1 / 2 \mathrm{~h}$ to remove organic contaminants. Using a common $100 \%$ phosphoric acid bath at $90^{\circ} \mathrm{C}, 20-50$ $\mu \mathrm{g}$ of sample were reacted and analysed using a GV Isoprime isotope ratio mass spectrometer. Isotope values are reported in delta notation relative to Vienna Peedee belemnite (Gonfiantini, 1984; Coplen, 1994). Repeated analyses of a marble working standard (calibrated against the international standard NBS-19) indicate an accuracy and precision of $0.1 \% 0(1 \sigma)$.

Five AMS radiocarbon dates were also obtained in cores KERO-07, KERO-20 and MD11-3342 (Table 2). For each measurement, about $10 \mathrm{mg}$ of $\mathrm{G}$. ruber and $\mathrm{G}$. 
sacculifer were picked from the $>125-\mu m$ fraction. The samples were analysed at the CEN Saclay, France (INSU Artemis program). Reported radiocarbon ages have been corrected for a marine reservoir effect of $400 \mathrm{yr}$ and converted to calendar years using CALIB Rev 6.0.1 (Stuiver and Reimer, 1993). Calibrated thousand years before present will be referred as cal ka BP.

\section{Results}

\subsection{Morphology of the Mafate turbidite complex}

The $115 \mathrm{~km}$ long and $80 \mathrm{~km}$ wide Mafate turbidite complex is composed of two coalescent-like fans (Fig. 3): the Mafate turbidite system and the Saint-Denis turbidite system. The Mafate turbidite system, located in the western part of the complex, is about $2500 \mathrm{~km}^{2}$. It is fed by the "Rivière des Galets" draining the "cirque" of Mafate catchment (about $108 \mathrm{~km}^{2}$ ). The Saint-Denis turbidite system covers an area of about $2000 \mathrm{~km}^{2}$ and is located in the eastern part of the complex. It is supplied by two main rivers: "Rivière Saint-Denis" (catchment of about $29 \mathrm{~km}^{2}$ ) and "Rivière des Pluies" (catchment of about $45 \mathrm{~km}^{2}$ ) and several smaller gullies (Figs. 3, 4). On the submarine upper slope, "La Montagne" volcanic massif forms a topographic high separating the two turbidite systems. Along the lower slope, canyons extend into two valley-like structures presenting channelized erosional features (Figs. 3, 4). These valleys enlarge downslope, leading to the broad and smooth areas of the abyssal plain. Two large sediment wave fields are also included in the complex: the first one on the western side of the Mafate turbidite system (western field) and the second one between the Mafate and the Saint-Denis turbidite systems (eastern field) (Fig. 3). The seabed in the bathymetry data around the turbidite systems is rugged and interpreted 
as large mass-wasting deposits. They form the main part of the submarine flanks of the volcanic edifice, as described by Oehler et al. $(2004,2008)$ and Le Friant et al. (2011).

Based on their morphological characteristics, the turbidite systems are divided into three morphological domains: canyons, valleys and distal areas (Figs. 3-5). In the upper part, canyons present a smooth floor and slopes ranging from $3^{\circ}$ to $13^{\circ}$. The Mafate turbidite system is fed by a wide canyon (about $3 \mathrm{~km}$ wide and more than 500 $\mathrm{m}$ deep) connected to the large "Rivière des Galets" delta (about $14 \mathrm{~km}$ wide and 6.5 $\mathrm{km}$ long), directly connected to a wide and smooth canyon head through a $10 \mathrm{~km}$ wide and smooth canyon head (canyon "a" in Figs. 3-5). The Saint-Denis turbidite system is fed by five canyons (canyons "a' ", "b", "c", "d" and "e" in Figs. 3-5). Three small canyons are visible west of La Montagne Massif, each less than $1 \mathrm{~km}$ wide and about $200 \mathrm{~m}$ deep. One of them is connected to the Mafate canyon at about $2000 \mathrm{~m}$ depth (canyon "a' ") and two other directly to the shelf, fed by several small gullies (canyons "b" and "c"). East of La Montagne Massif, the main canyon is connected to the "Rivière des Pluies" and the "Rivière Saint-Denis", and to several small gullies (canyon "d" in Figs. 3-5). This canyon is about $2 \mathrm{~km}$ wide and $300 \mathrm{~m}$ deep. The most easterly canyon is smaller (about $2 \mathrm{~km}$ wide and $100 \mathrm{~m}$ deep), connected to the shelf and fed by small gullies (canyon "e" in Figs. 3-5). Other canyons, apparently disconnected from the modern river network on land, can be observed in the masswasting deposits (Fig. 6). Downslope, along the channels, the slope gradient decreases to approximately $2^{\circ}$ (Fig. 5). The transfer axes become less incised (less than $100 \mathrm{~m}$ deep) and wider (from $5 \mathrm{~km}$ wide at the slope break, respectively at 2000 and $2500 \mathrm{~m}$ along both Mafate and Saint-Denis turbidite systems, to more than 15 $\mathrm{km}$ between the sediment wave fields). The channel areas are characterized by a 
floor rougher than in the canyons (Figs. 3, 4), showing blocks and marked, especially along the Mafate system, by braided channels (about $12 \mathrm{~km}$ long, $800 \mathrm{~m}$ wide and 20 to $30 \mathrm{~m}$ deep, Fig. 4c, profile 1) and dunes (wavelength ranging from $500 \mathrm{~m}$ to $1.5 \mathrm{~km}$ and height from 10 to $40 \mathrm{~m}$, Fig. 4c, profile 2). At the terminations of the channel areas, the transfer axes broaden and become smooth (of low relief).

The two turbidite systems show different slope profiles (Fig. 5). Similar to most continental slope channels, the Mafate turbidite system presents a smoothly concave-up profile. Conversely, the Saint-Denis turbidite system shows an unusual convex segment at the canyon/channel transition, between approximately 40 and 70 $\mathrm{km}$ from the coast (Fig. 5b). This "large bump" is particularly visible along the canyon "a' " that presents a rough floor with many small-scale irregularities tens of meters high (Figs. 4, 5).

The sediment wave field that separates the Mafate and the Saint-Denis turbidite systems, covering an area of $\sim 850 \mathrm{~km}^{2}$ with a $0.2^{\circ}$ slope gradient, is about $30 \mathrm{~km}$ long and $30 \mathrm{~km}$ wide at its widest end at $4400 \mathrm{~m}$ of water depth. The sediment-wave amplitude decreases downslope from more than $80 \mathrm{~m}$ to $10 \mathrm{~m}$, and their wavelengths decrease downslope from about $5 \mathrm{~km}$ for the shallowest sediment waves to less than $2 \mathrm{~km}$ for the deepest ones. Wave crests are roughly parallel to bathymetric contours. The sediment wave field bordering the western side of the Mafate turbidite system is about $30 \mathrm{~km}$ long and covers an area of about $700 \mathrm{~km}^{2}$. It presents similar morphological characteristics to the eastern field, showing decreasing wavelength downslope (from about $4 \mathrm{~km}$ for the shallowest sediment waves to less than $2 \mathrm{~km}$ for the depest ones), decreasing wave height (from more than $70 \mathrm{~m}$ to $10 \mathrm{~m}$ ) and wave crests roughly perpendicular to the maximum slope. In this field, the wave crests 
appear less continuous and smoother than in the eastern field where they are very regular.

\subsection{Surface sediment distribution of the Mafate turbidite complex}

High-resolution EM120 backscatter data (Fig. 6a, b) combined with small-scale sedimentary features imaged by TOBI side-scan sonar (Fig. 7a-c) provide detailed views of the channel floors and information interpretable in terms of near-surface (first meter) sediment type and grain-size. The high backscatter of the canyon floors is interpreted as coarse material (blocks, pebbles, gravels) (Fig. 6a). The canyon feeding the Mafate turbidite system and the canyon connected to the "Rivière des Pluies" and belonging to the Saint-Denis turbidite system are highly reflective. The other canyons feeding the Saint-Denis turbidite system present lighter backscatter tones, as do some of the disconnected canyons visible on the large bulges of masswasting deposits. Moreover, the canyon "a' " (Figs. 3, 5) between the Mafate and the Saint-Denis turbidite systems presents a different acoustic facies: lighter, speckled and disturbed, similar to the bordering mass wasting deposits. In this area, the sedimentary features imaged by the TOBI side scan sonar show a high backscatter and narrow canyon bypassing the adjacent submarine chaotic area ( "landslide deposits" in Fig. 7b).

In the valley axis, backscatter data highlight the channel networks. The channels are braided in the Mafate valley (Figs. 6b, 7a) and straighter, with a slightly radiating "plume-like" distribution, in the Saint-Denis valley (Figs. 6b, 7c). Except for a dark curved feature at the northern end of the Mafate turbidite system ("distal channel" on Fig.6a) that suggest the presence of coarser material, these channels end up about $70 \mathrm{~km}$ from the island, close to the sediment wave fields. In both turbidite systems, 
depositional bedforms are visible between the channels and present low-reflectivity facies (light grey tone). Small sediment waves are observed in the Mafate and the Saint-Denis turbidite systems and are more numerous in the Mafate valley. Some scours and erosional feature (washed-off areas or scarps) are also visible along the Mafate channels but are not observed along the Saint-Denis channels (Fig. 7a, c). The distal parts of both turbidite systems, which are flat and homogeneous on the bathymetric map, are characterized by low-reflectivity facies (white areas) related to sandy deposits (Fig. 6a). These acoustic facies spread out in the valley main axis and between the sediment waves. The sediment wave fields show alternating high and low backscatter. The lithological nature of dark grey areas located on the stoss sides of the sediment waves is interpreted as coarser sediments compared to the lee sides facies appearing in grey. Two secondary small sediment wave fields are also visible on to the backscatter map. The first one is located in the distal part of the Mafate turbidite system and the second one to the east of the Saint-Denis turbidite system (Fig. 6). In these fields, sediment waves are less regularly organized and have lower amplitudes than in the two main sediment wave fields.

\subsection{Seismic architecture of the Mafate turbidite complex}

Seismic reflection profiles reveal the vertical organization of sedimentary units observed along the turbidite systems. Seismic facies are classified based on the signal continuity, amplitude and organization (Fig. 8).

Mass-wasting deposits occupy a large volume on the flanks of the island. They are characterized by chaotic seismic facies with discontinuous, disorganized and variable-amplitude reflectors (Fig. 8). These mass-wasting deposits can be divided in two subgroups. The first unit (in dark green on the interpreted profiles of Fig. 8) 
presents very chaotic facies and sometimes comes out at the surface outcrops, forming an irregular sea-floor surface. The second unit (in light green) is slightly more organized, with a roughly irregular surface covered by a sediment layer.

Channels (in purple on the interpreted profiles of Fig. 8) present no levees. They incise the mass-wasting deposits and are characterized by shallow and highamplitude reflectors. In the distal part of the turbidite systems, the channel relief decreases, and only a superfical incision indicates the small channels supplying the distal lobes, such as one north of the Mafate turbidite system that intersects the seismic profile 02 close to the shot 2100 (Fig. 6) and located by a black arrow on the seismic profile 02 (Fig. 8).

Continuous and horizontal reflectors characterize the distal sediment deposits. Some of them are strong (high amplitude) and are organized in lenses, suggesting that they correspond to depositional lobes of turbidite systems (marked in pink on the interpreted profiles of Fig. 8). Other continuous reflectors show lower amplitude seismic facies, and form thick layers in the deepest parts of the seismic profiles (in red on the interpreted profiles of Fig. 8). Based on correlations with the sediment cores, they are assumed to be dominated by hemipelagic sediments interstratified with rare and thin turbidites. A thick seismic unit (the pre-avalanche deposit, represented in yellow in Fig. 8), with very continuous reflectors, can also be identified below the mass-wasting deposits and hemipelagic-dominated sediments.

The seismic data below the sediment waves (in blue on the interpreted profiles of Fig. 8) present high-amplitude and continuous reflectors, and downlapping terminations. They set up on the surface heterogeneities of the mass-wasting deposits (Fig. 8). The sediment waves present high amplitudes and long regular wavelengths in the proximal part (profile 21 on Fig. 8). They become smaller and less regular downslope 
(profile 02 on Fig. 8). The stoss side of sediment waves (profile 21 on Fig. 8) presents a lower gradient than the lee side.

\subsection{Sedimentological facies}

In the three cores collected along the Mafate turbidite system, turbidites are characterized by normally-graded volcaniclastic deposits ranging from fine sand to silt, containing fragments of basalt, glass shards, olivine, pyroxene and reworked foraminifera and clays (Table 1, Fig. 3).

The sedimentological description and grain-size analysis of KERO-07 core show a lithological succession dominated by silty-clay and silt (Fig. 9a). The base of KERO07 , from 332 to $272 \mathrm{~cm}$ bsf (below sea floor), is mainly of silty-clay sediments.

Between 272 and $260 \mathrm{~cm}$ bsf, sediments are mainly composed of silty to silty-clay with small clay beds. From $260-183 \mathrm{~cm}$ bsf, two silty turbidites occur (from $216-210$ $\mathrm{cm}$ bsf and from $196-183 \mathrm{~cm}$ bsf). From $182-134 \mathrm{~cm}$ bsf, the silty-clay deposits dominate, punctuated by small silty beds and a turbidite between 165 and $160 \mathrm{~cm}$ bsf. From $133-0 \mathrm{~cm}$ bsf, sediment is roughly homogeneous, with thick silty deposits and some silty-clay layers.

KERO-20 core is dominated by volcanic sands (Fig. 9b). The base of KERO-20 is mainly made of silty-clay sediments with thin silty turbidites (affected by piston coring deformation) in the deepest section (490 - $400 \mathrm{~cm}$ bsf). A thick sandy deposit is identified between 370 - $350 \mathrm{~cm}$ bsf, showing parallel laminations. From 350 - 290 $\mathrm{cm}$ bsf the core shows reworked deposits of medium grain-size sand in a silty-clay matrix. This disturbance in the deposits is assumed to be the result of small local mass movements during deposition or piston coring deformation. Except for a clayrich interval between $215-235 \mathrm{~cm}$ bsf, the entire section, from $290-190 \mathrm{~cm}$ bsf, is 
filled by a turbidite deposit of coarse, normally-graded volcaniclastic sand, with the presence of mud clasts at the base of the sequence. The next upper $45 \mathrm{~cm}$ present an alternation of normally graded silty to very fine sandy turbidites on a silty-clay base, some of them showing parallel laminations. Between $144-90 \mathrm{~cm}$ bsf, a thick turbidite deposit is characterized by normally-graded accumulation from very fine volcaniclastic sand to silt above an erosive base. The top of KERO-20 (90 - $0 \mathrm{~cm}$ bsf) is composed of alternating silt-clay and silt turbidites.

The MD11-3342 core is characterized by silty and silty-clay volcaniclastic beds alternating with hemipelagic clay intervals (Fig. 9c). The base of MD11-3342, from $1889-1280 \mathrm{~cm}$ bsf, is composed of numerous thin silty layers alternating with hemipelagic clay. The turbidite deposits are mostly about $1-2 \mathrm{~cm}$ thick. Thicker turbidite beds, about $10 \mathrm{~cm}$ thick, have normal grading between $1452-1302 \mathrm{~cm}$ bsf and between $1889-1752 \mathrm{~cm}$ bsf. From 1280 - $850 \mathrm{~cm}$ bsf, intervals between the turbidite deposits increase. Turbidites are about $5 \mathrm{~cm}$ thick, and are composed of very fine sandy layers above an erosive base and grade to silty-clay at the top. The thickest turbidite bed is $75 \mathrm{~cm}$ thick (1100 - $1025 \mathrm{~cm}$ bsf) with laminations containing reworked foraminifera in the sandy unit and silty laminations at the top of the turbidite. From $850-770 \mathrm{~cm}$ bsf, the core presents silty disturbed lenses in a clay matrix. From $770-396 \mathrm{~cm}$ bsf, turbidite layers frequency increases again. The sequences are about $5-15 \mathrm{~cm}$ thick, presenting normal grading, erosive bases, and sparse horizontal laminations at the top. Between $396-359 \mathrm{~cm}$ bsf, a thick turbidite deposit consists of volcaniclastic fine sand above an erosive base, overlain by normally graded and laminated silty-clay layers. From $300-0 \mathrm{~cm}$ bsf, turbidites thinner than $5 \mathrm{~cm}$ are numerous. 


\subsection{Oxygen isotopic stratigraphy, ${ }^{14} \mathrm{C}$ dating and Ca correlations}

$\mathrm{KERO}-07$ is the core presenting the most hemipelagic and continuous sedimentation.

The KERO-07 $\delta^{18} \mathrm{O}$ curve (Fig. 9a) shows heavy $\delta^{18} \mathrm{O}$ values at about $-0.5 \%$ PDB in the lower part of the core. A rapid decrease of the $\delta^{18} \mathrm{O}$ signal is observed between $300-225 \mathrm{~cm}$ bsf, with values falling from -0.5 to $-2.0 \%$ PDB. The upper part of the core (from 225 - $1 \mathrm{~cm}$ bsf) presents light values between -2 and $-1.5 \%$ PDB, with a maximum of $-1.62 \%$ at $220 \mathrm{~cm}$ bsf.

Peaks and troughs of this oxygen isotope record were correlated with the isotopic signal published by Fretzdorff et al. (2000) for the first $80 \mathrm{~cm}$ of the core S17-666, which was recovered on the mass-wasting deposits west of the Mafate turbidite complex (Figs. 3, 10a). The KERO- $07 \delta^{18} \mathrm{O}$ record has been also correlated to the $\delta^{18} \mathrm{O}$ EPICA Dome C record (Parrenin et al., 2007) (Fig. 10a). The late Quaternary (Marine Isotope Stage 2) corresponds to the light $\delta^{18} \mathrm{O}$ values (about -56 \%) between 25 and $18 \mathrm{ka}$, followed by a lightening of these values (up to $-50 \%$ ) during the glacial-interglacial transition (18 to $11.5 \mathrm{ka}$ ). The Holocene is indicated by stable $\delta^{18} \mathrm{O}$ values (between -51 and $-49 \%$ ) from 11.5 ka to the present (MIS 1) (Fig. 10a). The KERO-20 stratigraphy was indirectly established by correlating XRF Ca variations measured on both KERO-07 and KERO-20 cores (Figs. 9, 10b). These correlations, supported by three radiocarbon dates (two in KERO-07 and one in KERO-20), show that KERO-07 and KERO-20 cores record deposition covering the last 25 ka and 23 ka respectively (Fig. 10). Based on this age model, the sedimentation rates observed in the Mafate turbidite system appear highly variable, ranging in the hemipelagic sediments from $2-24 \mathrm{~cm} / \mathrm{ka}$ for KERO 07 (average rate: $12 \mathrm{~cm} / \mathrm{ka}$ ) and from 5 - $40 \mathrm{~cm} / \mathrm{ka}$ for KERO 20 (average rate: $11 \mathrm{~cm} / \mathrm{ka}$ ) (Fig. 11). The turbidite activity increases these rates up to a maximum of $334 \mathrm{~cm} / \mathrm{ka}$ for KERO 07 
and $844 \mathrm{~cm} / \mathrm{ka}$ for KERO 20 in the thickest turbidite deposits, with respectively average rates of 14 and $22 \mathrm{~cm} / \mathrm{ka}$. Considering the average hemipelagic sedimentation rates in both cores and the $\delta^{18} \mathrm{O}$ sampling interval, the accuracy of the age model is estimated at \pm 454 years

\section{Discussion}

\subsection{Architecture and sedimentary processes of the Mafate complex}

The Mafate and Saint-Denis turbidite systems are divided in three parts: canyons, channels and depositional distal lobes, in agreement with subdivisions established for the Cilaos turbidite system, on the southern submarine flank of La Réunion Island (Saint-Ange et al., 2011; Sisavath et al., 2011). Canyons are characterised by a smooth floor and a high-reflectivity facies corresponding to coarse and heterogeneous material (pebbles and m-scale blocks as observed in the rivers on land) and testifying to intense erosional processes. Channels, revealed by the TOBI images (Fig. 7), are poorly incised and do not present levees. They channelize the sandy turbidity flows and are floored by coarse stacked sand or gravel, and probably finer facies on the sides forming bedforms and small sediment waves. The disappearance of the channels at some distance from the coast may imply the end of coarse material being at the surface of the sea floor, and possibly the end of high density turbidity currents. Alternatively, the distal channel floors may have simply become draped with finer sediment that absorbs the acoustic signal. The occurrence of the erosional features, such as channels, gullies and scours, suggests a decrease of erosion downslope. Depositional lobes constitute the majority of turbidite deposits and mostly correspond to thick sandy and silty residual sediments, as observed in 
KERO-20. Part of this material spreads in the sediment wave fields and participates in the sediment wave growth, but also over the abyssal plain as observed within core MD11-3342. The extension of the largest turbidites exceeds the lobe limits defined by the white areas on the backscatter images. These areas probably correspond to the limit of thickest sandy facies.

The morphological analysis suggests that a connection between the Mafate and Saint-Denis turbidite systems has been active through a canyon located downslope of La Montagne Massif (canyon "a' ", in Fig. 7). In this area, the combination of a chaotic and high-relief slope profile (Figs. 4,5 ) with a disturbed and poorly reflective acoustic facies (Figs. 6, 7b) allow us to interpret this zone as deposits from a submarine landslide (Fig. 6b), whose origin would be located up the canyon "a' ", as also suggested by Oehler et al. (2008). The extension of the landslide deposit area should correspond to the "large bump" (convex segment) observed along the SaintDenis turbidite system (Fig. 5). This submarine landslide has probably closed a paleo-canyon connecting the outlet of the "cirque" of Mafate watershed to the SaintDenis turbidite system. After this submarine landslide event, the turbidity currents generated near the "Rivière des Galets" mouth would have been deflected to the west, creating or enlarging the present Mafate turbidite system. This hypothesis is supported by the detailed sedimentary features imaged by the TOBI side-scan sonar showing a very dark and narrow canyon that bypasses the adjacent submarine landslide deposits (Fig. 7b). This abrupt change of canyon pathway likely corresponds to an avulsion episode. While these avulsions are common for turbidite channels, especially in large mature siliciclastic deep-sea fans (Damuth et al., 1988; Manley and Flood, 1988; Pirmez and Flood, 1995; Popescu et al., 2001; Droz et al., 2003), they are relatively uncommon along canyons. In the case of the Mafate 
turbidite system, the avulsion can be explained by the instability of the landslide deposits that form the very steep submarine flanks of the volcanic edifice.

The high erosion rates in the "cirques" and rivers (Louvat and Allègre, 1997; Rad et al., 2007), and the dense hydrographic network of La Réunion Island, allow the transport of large amounts of volcaniclastic products to the submarine flanks of the island, particularly during cyclonic rainfalls. The straight connection between the hydrographic network and the canyon heads suggest a strong influence of the onshore erosional processes and climatic events in the feeding of the Mafate and Saint-Denis turbidite systems. Considering the models of Krastel et al. (2001) and Mitchell et al. (2003) for the Canary Islands, sedimentary transfer in such settings occurs as hyperpycnal flows. In La Réunion, this hypothesis has been illustrated by the continuity from fluvial axis to submarine canyon heads in the Cilaos turbidite system (Babonneau et al., 2013), and the hyperpycnal flows identified as the main processes of sediment transfer in the submarine canyons (Saint-Ange et al., 2011, Sisavath et al., 2011). The Mafate turbidite system, which presents a large watershed connected to a wide and smooth canyon head, is likely the seat of a similar direct activity. In addition, turbidite flows are probably generated from the sediments deposited progressively at canyon heads or on the narrow shelf during smaller floods that become unstable and fail when a loading threshold is reached. It is difficult to estimate if these flows have enough energy to carry on through the canyons and reach the distal areas. If not, they might induce successive accumulations of sediments in the proximal areas until again the loading threshold is reached. Morphological and sedimentological data (dimensions of the watersheds, transfer axes and depositional areas, development of the channel network, presence or absence of erosional features, etc) can also be used to compare the contrasting 
activity of the two turbidite systems of the Mafate complex. The large watershed of the Mafate turbidite system $\left(108 \mathrm{~km}^{2}\right)$, combined with the high erosional and sediment flow rates from the "Rivière des Galets", leads to direct and strong transfers of large amounts of coarse material in the wide and deep Mafate canyon. The absence of sedimentary cover on the mud penetrator profiles collected along the Mafate complex (and not presented in this study) confirms its recent activity, as well as the numerous braided channels, erosional features and scours visible on backscatter data (Figs. 4, 6, 7) and the overflow turbidite deposits preserved in core KERO-07 (Fig. 9a). The catchment area of the Saint-Denis turbidite system is smaller $\left(74 \mathrm{~km}^{2}\right)$, and the "Rivière Saint-Denis" younger than the "Rivière des Galets" (Haurie, 1987; Arnaud, 2005). The dimensions of the Saint-Denis turbidite system are also smaller (about $2000 \mathrm{~km}^{2}$ vs. $2500 \mathrm{~km}^{2}$ for the Mafate turbidite system), with land to sea connections going through numerous small canyons. The "plume-like" channels and erosional features are less developed than in the Mafate turbidite system (Figs. 6, 7). Nevertheless, the very deep, large and filled channel visible in Fig.8, Profile 21, shots $500-300$ might be the relict of a past strong activity of the Saint-Denis turbidite system, before the submarine landslide closed its connection with the "cirque" of Mafate watershed. The creation of the present Mafate turbidite system should therefore be responsible for a decrease of the Saint-Denis turbidite activity and a filling of its distal channels. Thus, the sedimentary processes seem less strong in the Saint-Denis turbidite system than in the Mafate turbidite system and its present activity mainly concentrated in the "Rivière des Pluies" canyon where the EM120 data show the highest backscattering.

Cores KERO-07 and MD11-3342 are not directly located in the turbidite complex identified from the interpretation of seismic and backscatter data. Core KERO-07 is 
located in the proximal submarine slope, outside of the canyon, and core MD11-3342 is located in the abyssal plain outside of the depositional lobes. The presence of turbidites in both cores suggests that the turbidite systems are not restricted to the mapped systems but are instead spread more widely across low angle abyssal slopes. The largest turbidity flows probably exceed the mapped limits. As shown by the core KERO-07 (Fig. 9a), fine-grained turbidites are identified on the edge of the canyon. Given the incision height $(400 \mathrm{~m})$ of the Mafate canyon near the core and the muddy (silty-clay) facies of turbidites, the turbidite record of core KERO-07 might correspond to the canyon overflow of the largest turbidity currents initiated in the Mafate canyon head. In the distal basin, the numerous silty and sandy beds described in MD11-3342 core (about $25 \%$ of the whole core lenght, Fig. 9c) show that volcaniclastic deposits spread far over the abyssal plain. These turbidite deposits, located outside of the white areas identified from the backscatter images, could be the result of: (1) widespread turbidity currents from the Mafate turbidite system, and correspond to the distal sedimentary record of the largest turbidite events, (2) turbidity currents generated in short canyons located in the submarine slope at the southwest of the Mafate canyon without a direct sediment feeding from the coast.

\subsection{Mass-wasting deposits and the origin and development of sediment waves}

Oehler et al. $(2008,2004)$, state that the chaotic terrains forming the major part of the submarine flanks of La Réunion Island are debris avalanche deposits resulting from large collapses of the volcano flanks, usually with a subaerial source area, and sometimes with a submarine source area. According to Le Friant et al. (2011), these chaotic deposits at Piton des Neiges are not the result of large flank landslides but 
the consequence of small superficial landslides or slow sediment deformation in response to the spreading of La Réunion volcanic edifice. Whatever their origin, rough and chaotic terrains constitute large and chaotic units (Figs. 3, 7) on which density currents propagate.

The KERO-20 core (Fig. 9) indicates that sediment waves of the Mafate turbidite complex are mainly made up of fine sandy turbidites alternating with hemipelagic deposits. According to Wynn and Stow (2002), these landforms should therefore be classified as coarse-grained turbidity current sediment waves, but the dimensions of coarse-grained sediment waves described in the literature are much smaller, in both wavelength and amplitude (with wavelength up to $1 \mathrm{~km}$ and wave amplitude up to 10 $\mathrm{m})$, than those observed in the Mafate turbidite complex. The dimensions of the sediment waves of the Mafate turbidite complex are up to $5 \mathrm{~km}$ in wavelength and up to $80 \mathrm{~m}$ in amplitude. They are more in agreement with those proposed for finegrained turbidity current sediment waves, with wavelength up to $7 \mathrm{~km}$ and wave amplitude up to $80 \mathrm{~m}$ (Wynn and Stow, 2002). The seismic profiles acquired along the sediment wave field (Fig. 8) show underlying chaotic mass-wasting deposits that may explain these differences in size, by offering a setting which influence and increases sediment wave dimensions. Covering these large-scale pre-existing heterogeneities, sandy supply from the turbidity currents contribute to the formation and growth of large sediment waves (Lee et al., 2002). The thick hemipelagic intervals deposited between the sandy turbidite deposits (Bouma, 1962) might also provide a fine and cohesive material (clay or silty-clay) that contributes to increase the dimensions of the sediment waves (closer to fine-grained turbidity current sediment waves). The downslope decreasing size of the sediment waves may be related to a slowing down of the turbidity current (Normark et al., 1980), a reduction 
of the sand components, and/or the decreasing heterogeneities of the underlying chaotic.

The presence of isolated and active canyons on the submarine slopes, disconnected from the coastline, suggests the existence of other secondary gravity processes, independent from the turbidite complex activity. (Fig. 6). As suggested by Le Friant et al. (2011), the local erosion of the mass-wasting deposits leads to submarine destabilisations, and to the formation of unconfined turbidity currents on the submarine flanks of the island. This sediment supply might participate in the building of the sediment waves distributed at the toe of La Réunion edifice, covering the heterogeneities created by the mass-wasting deposits.

The reflectivity contrasts in backscatter images between the wave sides and the asymmetric flanks of the sediment waves suggest fine and very fine sand (dark grey on the backscatter map) on the less developed stoss flank, and finer deposits with silt and silty-clay (light grey) on the more developed lee flank. Sediment profiler records in this area do not image the subsurface (presumably because of the sand), and cannot reveal migration of the sediment waves, but previous studies suggest that an upslope/upcurrent migration is probable (Lee et al., 2002; Wynn et al., 2002).

\subsection{Comparison between the Cilaos turbidite system and the Mafate turbidite complex}

While they both result from the Piton des Neiges volcano dismantling, the Mafate turbidite complex and the Cilaos turbidite system show contrasted morphologies. The two feeding areas of the Cilaos turbidite system (the "cirque" of Cilaos and the "Bras de la Plaine" river watersheds, both about $100 \mathrm{~km}^{2}$ ) merge into a unique and large deep-sea fan with depositional lobes divided by sub-parallel volcanic ridges (Saint- 
Ange et al., 2011; Sisavath, 2011; Sisavath et al., 2011). Conversely, the two feeding areas of the Mafate complex (the "cirque" of Mafate and the "Rivière des Galets" and "Rivière des Pluies" watersheds) feed the two independent turbidite systems of Mafate and Saint-Denis respectively. Both of them are smaller than the Cilaos turbidite system $\left(15,000 \mathrm{~km}^{2}, 300 \mathrm{~km}\right.$ long and $120 \mathrm{~km}$ wide for the Cilaos deep-sea fan and $7000 \mathrm{~km}^{2}, 115 \mathrm{~km}$ long and $80 \mathrm{~km}$ wide for the entire Mafate turbidite complex) and present a more simple geometry with two depositional areas bordered by large sediment wave fields. The closure of the past connection between the Mafate and Saint Denis turbidite systems, and the resulting split in the sedimentary flux, should partly account for these smaller sizes, as both systems may not have yet reached the size and morphological maturity of the Cilaos turbidite system. By analogy with the study done on the Cilaos fan (Sisavath, 2011; Sisavath et al., 2011), the very shallow penetration of mud-penetrator profiles and the samples collected in the turbidite deposits of the cores (volcanic sand, scoria, pyroxene, olivine and felspar debris, glass shards, etc) indicate that the Mafate complex is a sand-dominated system, even in its distal parts. For the Mafate, Saint-Denis and Cilaos turbidite systems, channel levee structures are absent, and the transfer axes directly incise the mass-wasting deposits. The very erosive and highly concentrated sandy debris flows might explain this particularity.

\subsection{Stratigraphy and controlling factors of the turbidite activity}

The sedimentation rates measured in KERO-07 and KERO-20 (Fig. 11) are higher than those previously calculated around La Réunion Island in \$17-666, ranging from $1.65-12 \mathrm{~cm} / \mathrm{ka}$ (Fretzdorff et al., 2000) and in cores sampled in the Cilaos turbidite system, estimated to be a few $\mathrm{cm} / \mathrm{ka}$ (Sisavath et al., 2011, 2012). This high range of 
sedimentation rates could be explained by the core locations. Cores collected in the Cilaos fan are located far from the island at water depth deeper than $3500 \mathrm{~m}$. They are poorly fed by detrital material, and can be partly affected by carbonate dissolution (as observed on foraminifera in Sisavath et al., 2012). KERO-07 core, sampled in a mini-basin at $800 \mathrm{~m}$ water depth, records fallout from river mouth plumes and overflows of turbidity currents, and probably the products of unconfined turbidity currents from the submarine slope of the volcano. KERO-20 core, collected closer to the active system and the depositional lobes, receives the largest amount of sediment. This core may be considered as the most representative of the Mafate turbidite system activity.

Based on the stratigraphic models established for KERO-07 and KERO-20 cores, the approximated ages of the turbidite events can be estimated. The results suggest that turbidite events mainly occurred between 24 - $18 \mathrm{ka}$, and since $8 \mathrm{ka}$, plus two isolated events at about 14 and $12 \mathrm{ka}$ (Fig. 12).

Piton des Neiges volcano probably ended its activity about 29 to 22 ka ago (Gillot and Nativel, 1982; Delibrias et al., 1986; Kluska, 1997). A younger age of $12 \pm 3 \mathrm{ka}$, obtained by the U-Th method on pyroclastic deposits (Deniel et al., 1992), was questioned by Salvany et al. (2012) as it does not correlate with ages obtained on the same deposits from other methods. Most of the turbidite activity of the last $25 \mathrm{ka}$ observed in the Mafate turbidite system occurs after the end of the eruptive activity at Piton des Neiges volcano. This is consistent with the hypothesis proposed by Sisavath et al. (2012) observing the Cilaos activity record over the last 140 ka. During the Piton des Neiges volcanic activity, the turbidite activity stopped, due to the invasion of watersheds and rivers by lava and pyroclastic flows. Conversely, a 
recovery of onland erosive processes, and an increase of the submarine sediment supply, is observed during volcanic quiescence phases.

The turbidite activity of the Mafate system has been compared to a climate proxy: the branched and isoprenoid tetraether (BIT) index calculated for Lake Challa in equatorial eastern Africa (Fig. 12), which could be an indicator of the past climate in La Réunion Island as it also depends on monsoon rainfalls coming from the western Indian Ocean (Verschuren et al., 2009). This comparison reveals that the turbidite activity occurs during both dry and wet periods, with a slightly higher turbidite frequency during wet periods. The absence of a direct relationship between climate and turbidite activity is consistent with the rare ecosystem variations observed on Mauritius (200 km north of La Réunion) over the last $35 \mathrm{ka} \mathrm{(De} \mathrm{Boer} \mathrm{et} \mathrm{al.,} \mathrm{2013),}$ which might be the consequence of stable regional climatic conditions maintained by the permanent circulation of wet air masses over the Indian Ocean (Verschuren et al., 2009).

The commonly accepted lowstand system tract model (Mutti, 1985; Posamentier and Vail, 1988; Weimer, 1990; Vail et al., 1991; Flood and Piper, 1997) assumes that the feeding of deep turbidite systems starts during a fall of sea level when rivers reach the outer continental shelf and entrench into the shelf edge. Turbidite systems increase to their maximum during the lowstand period, with sediments directly conducted to the deep-basin via canyons (Johannessen and Steel, 2005), and continue only until the start of the next sea-level rise. Conversely, during the sealevel highstand, sediment supplies from rivers are stored on the shelf where space is available, and the deep sea fan is draped by hemipelagic sediments (Stow et al., 1984; Damuth et al., 1988; Feeley et al., 1990). This model explains the activity of the Mafate turbidite system until 8 ka (i.e., frequent turbidite deposits until 18 ka during 
the lowstand period and lack of activity between 18 - $8 \mathrm{ka}$ as the sea level rises), but seems inconsistent with the deposits observed during the Holocene (Fig. 12). Alternative models were proposed for deep-sea fans in narrow shelf or extremely high supply settings (e.g., California Borderland, Gulf of Corinth, Mediterranean Sea, Lance-Fox Hills-Lewis system, Bengal Fan, Zaïre fan; see Ito and Masuda, 1988; Weber et al., 1997; Piper and Normark, 2001; Khripounoff et al., 2003; Carvajal and Steel, 2006; Covault et al., 2007). In these cases, the turbidite activity observed during sea level rise and highstand is supported by sediment supplies from littoral drift or rivers (normal or heavy loads), and transported through canyons extending almost to the shoreline or deltas crossing narrow shelves. The Mafate turbidite system brings together several of these criteria: narrow shelf which is $30 \mathrm{~m}$ wide in this area, direct sediment transfer from river to submarine canyons, high erosion rates on land and turbidite activity recorded throughout the Holocene, and could therefore easily display and record a permanent turbidite activity during volcanic quiescence phases.

Assuming that our cores only record the largest events that can overflow the canyon wall and reach the distal areas, the Holocene turbidite activity of the Mafate turbidite system could be the consequence of: 1 ) direct large sedimentary transfers from river mouth to canyon head (e.g., during cyclonic floods), and/or 2) a rapid filling of the narrow shelf by sediments from land erosion (maybe through the building of the delta during the early Holocene), quickly reaching loading threshold and leading to large destabilisations recorded down to the distal parts of the turbidite system. In addition, two hypotheses might explain the lack of turbidite activity observed in the Mafate system between 18 - 8 ka: 1) the rapid sea-level variation that increases slope instability leading to more frequent but smaller and less powerful currents, rarely 
preserved in the cores, and/or 2) a shift in the depositional area (lobe migration) farther from core KERO-20 and thus not recorded in our data.

\subsection{Flow modelling and perspectives}

Although the simulation of gravity flows is not the purpose of this study, the Mafate-

Saint-Denis turbidite complex, and on a larger scale all the turbidite systems around La Réunion Island, may represent valuable application in the field of flow modelling. The Mafate turbidite complex morphology is fairly simple, with feeding areas well identified and sedimentary supplies directly driven to the submarine canyons and channels without disturbances from other processes. Regarding to those elements, La Réunion Island and the Mafate turbidite complex appear relevant to help the building of flow models. In that perspective, the geophysical dataset collected along the Mafate turbidite complex could be used to calibrate and validate physics-based real two-phase mass flow models that simulate the mobility and run-out of submarine landslides, avalanches or turbidity currents, or the submarine wave propagation (Iverson, 1997; Iverson and Denlinger, 2001; Pudasaini et al., 2005). Among these real two-phase mass flow models that involve a mixture of solid particles and viscous fluids, the general mass flow model by Pudasaini (2012) extends to subaerial and submarine mass movements and also models erosional-depositional behaviour and dynamic strength weakening during motion (Pudasaini, 2014; Pudasaini and Krautblatter, 2014).

After validation, this general mass flow models may be specifically applied to the Mafate turbidite complex to support some of our hypothesis. The flow modelling and simulation may help to better understand some aspects of this study that are hardly directly measurable from our data or generally in complex submarine environments 
i.e., the extension of the turbidite deposits in the distal parts of the turbidite complex, the interactions between the turbidity currents and the mass-wasting deposits, the contrast between the Mafate and the Saint-Denis turbidite system activities, and the building and propagation of sediment waves. Flow modelling, especially through land to sea integrated studies, would also be of great interest in the evaluation of the geohazards and risks related to subaerial and submarine mass movements by providing information about the mechanics, dynamics and runout distances of such events, and predicting the volumes of material involved.

\section{Conclusions}

This study presents the first morphological description of the Mafate turbidite complex on the northwestern submarine flank of La Réunion Island. This complex is formed by two separate turbidite systems, the Mafate turbidite system and the Saint-Denis turbidite system. The Mafate turbidite system is fed by the "Rivière des Galets" draining the large watershed of the "cirque" of Mafate; whereas the Saint-Denis turbidite system depends on several rivers and gullies, the most important of them being the "Rivière des Pluies". The direct connection between the hydrographic network and the canyons suggests that the sandy volcaniclastic sediment was carried by turbidity currents, probably through hyperpycnal flows, that depend on erosional processes on land.

The two turbidite systems are divided into three main areas: the canyons area, the channels area and the depositional lobes. The morphological and sedimentary analyses, particularly the high resolutions backscatter data and TOBI side-scan sonar images, reveal that the Mafate turbidite system is more mature and active than the 
Saint-Denis turbidite system. The surrounding large mass-wasting deposits, that form the main part of the flanks of the island, are incised by the deep canyons and the channel network of the two turbidite systems. Two sediment wave fields are associated with the turbidite complex, their waves developing on the chaotic substratum thank to the sedimentary supplies from the turbidity currents.

The cores collected along the Mafate turbidite system support a stratigraphic model and offer an overview of the turbidite activity in this system during the last $25 \mathrm{ka}$. High turbidity current activity occurred after the end of the eruptive activity of the Piton des Neiges volcano, during a period of quiescence dominated by subaerial erosion. This turbidite activity, for what it can be witnessed by our sampling, does not appear to depend only on sea level but is more probably continuous as a result of the narrow shelf and the high erosion setting of the turbidite system. The sandy deposits recorded in our cores testify to this strong activity, but also highlight the existence of unconfined turbidity currents related to secondary instabilities affecting the masswasting deposits. The volcaniclastic sediments carried by these currents are distributed on the submarine slope and over the abyssal plain even far from the turbidite complex.

\section{Acknowledgements}

We thank the crew and scientific teams of the 2006 FOREVER and ERODER 1 cruises, the 2008 ERODER 2, the 2010 ERODER 3 and 2011 ERODER 4 cruises for the recovery of a high quality dataset. Financial support was provided by the Conseil Régional de La Réunion, by the Institut Universitaire Européen de la Mer (Brest), by IFREMER and the Direction Générale de l'Armement. We are indebted to Laurent Emmanuel and Nathalie Labourdette (Université Pierre \& Marie Curie, Paris VI) who 
managed and ran oxygen isotope analyses, and to the Artemis Program (supported by the CNRS) for radiocarbon dating presented in this paper.

\section{References}

Acosta, J., Uchupi, E., Muñoz, A., Herranz, P., Palomo, C., Ballesteros, M., 2003. Geologic evolution of the Canarian Islands of Lanzarote, Fuerteventura, Gran Canaria and La Gomera and comparison of landslides at these islands with those at Tenerife, La Palma and El Hierro. Marine Geophysical Research 24, $1-40$.

Alley, R.B., Clark, P.U., Huybrechts, P., Joughin, I., 2005. Ice-Sheet and Sea-Level Changes. Science 310, 456-460.

Arnaud, N., 2005. Les processus de démantèlement des volcans, le cas d'un volcan bouclier en milieu océanique le Piton des Neiges, lle de la Réunion, Université de La Réunion, La Réunion, France.

Averous, P., 1983. Esquisse géomorphologique des atterrages de l'lle de la Réunion + Carte au 1/200000e. Terres Australes et Antarctiques Françaises, Paris, France.

Babonneau, N., Delacourt, C., Cancouët, R., Sisavath, E., Bachèlery, P., Mazuel, A., Jorry, S.J., Deschamps, A., Ammann, J., Villeneuve, N., 2013. Direct sediment transfer from land to deep-sea: Insights into shallow multibeam bathymetry at La Réunion Island. Marine Geology 346, 47-57.

Bachèlery, P., Villeneuve, N., 2013. Hot Spots and Large Igneous Provinces. In: Shroder, J.F. (Eds.), Treatise on Geomorphology. Academic Press, San Diego, pp. 193-233. 
Baltzer, A., Untersech, S., Voisset, M., 2000. L'imagerie acoustique sous-marine, que voit-elle réellement ?. In: Revue Française de Génie Civil. Presented at the Journées Nationales Génie Civil \& Génie Côtier, Lavoisier, pp. 1015-1029.

Bouma, A.H.,1962. Sedimentology of some flysch deposits; a graphic approach to facies interpretation. Amsterdam, Elsevier Pub. Co, pp. 168.Boudon, G., Friant, A.L., Komorowski, J.-C., Deplus, C., Semet, M.P., 2007. Volcano flank instability in the Lesser Antilles Arc: Diversity of scale, processes, and temporal recurrence. Journal of Geophysical Research 112, B08205, doi: 10.1029/2006JB004674.

Bret, L., Join, J.-L., Legal, X., Coudray, J., Fritz, B., 2003. Argiles et zéolites dans l'altération d'un volcan bouclier en milieu tropical (Le Piton des Neiges, La Réunion). Comptes Rendus Geoscience 335, 1031-1038.

Carvajal, C.R., Steel, R.J., 2006. Thick turbidite successions from supply-dominated shelves during sea-level highstand. Geology 34, 665-668.

Casalbore, D., Romagnoli, C., Bosman, A., Chiocci, F.L., 2011. Potential tsunamigenic landslides at Stromboli Volcano (Italy): Insight from marine DEM analysis. Geomorphology 126, 42-50, doi: 10.1016/j.geomorph.2010.10.026. Casalbore, D., Romagnoli, C., Chiocci, F.L., Frezza, V., 2010. Morphosedimentary characteristics of the volcaniclastic apron around Stromboli volcano (Italy). Marine Geology 269, 132-148.

Cochonat, P., Lénat, J.-F., Bachèlery, P., Boivin, P., Cornaglia, B., Deniel, C., Labazuy, P., Le Drezen, E., Lipman, P.W., Ollier, G., Savoye, B., Vincent, P.M., Voisset, M., 1990. Importances des dépôts gravitaires dans la mise en place d'un système volcano-sédimentaire sous-marin (volcan de la Fournaise, 
Ile de La Réunion). Comptes Rendus de l'Academie des Sciences Serie II $311,679-686$.

Coplen, T.B., 1994. Reporting of stable hydrogen, carbon, and oxygen isotopic abundances. Pure and Applied Chemistry 66, 273-273.

Covault, J.A., Normark, W.R., Roman, B.W., Graham, S.A., 2007. Highstand fans in the California borderland: The overlooked deep-water depositional systems. Geology 35, 783-786,

Damuth, J.E., Flood, R.D., Kowsmann, R.O., Belderson, R.H., Gorini, M.A., 1988. Anatomy and Growth Pattern of Amazon Deep-Sea Fan as Revealed by LongRange Side-Scan Sonar (GLORIA) and High-Resolution Seismic Studies. AAPG Bulletin 72, 885-911.

De Boer, E.J., Hooghiemstra, H., Vincent Florens, F.B., Baider, C., Engels, S., Dakos, V., Blaauw, M., Bennett, K.D., 2013. Rapid succession of plant associations on the small ocean island of Mauritius at the onset of the Holocene. Quaternary Science Reviews 68, 114-125.

Delibrias, G., Guillier, M.-T., Labeyrie, J., 1986. GIF natural radiocarbon measurement X. Radiocarbon 28, 64-65.

Deniel, C., Kieffer, G., Lecointre, J., 1992. New ${ }^{230} \mathrm{Th}^{238} \mathrm{U}$ and ${ }^{14} \mathrm{C}$ age determinations from Piton des Neiges volcano, Reunion - A revised chronology for the differentiated series. Journal of Volcanology and Geothermal Research 51, 253-267.

Denlinger, R.P., Morgan, J.K., 2014. Instability of Hawaiian volcanoes. In: Poland, M.P., Takahashi, T.J., Claire M. Landowski, C.M. (Eds), Characteristics of Hawaiian Volcanoes. U.S. Geological Survey, Reston, VA, USA, Professional Paper 1801, pp. 149-176. 
Deplus, C., Le Friant, A., Boudon, G., Komorowski, J.-C., Villemant, B., Harford, C., Ségoufin, J., Cheminée, J.-L., 2001. Submarine evidence for large-scale debris avalanches in the Lesser Antilles Arc. Earth and Planetary Science Letters 192, 145-157.

Droz, L., Marsset, T., Ondréas, H., Lopez, M., Savoye, B., Spy-Anderson, F.-L., 2003. Architecture of an active mud-rich turbidite system: The Zaire Fan (Congo-Angola margin southeast Atlantic) Results from ZaïAngo 1 and 2 cruises. AAPG Bulletin 87, 1145-1168.

Duncan, R.A., Backman, J., Peterson, L., The Shipboard Scientific Party, 1989. Reunion hotspot activitity through tertiary time: Initial results from the ocean drilling program, leg 115. Journal of Volcanology and Geothermal Research 36, 193-198.

Fevre, Y., 2005. Mécanismes et vitesses d'érosion à l'échelle géologique sur une île volcanique jeune à relief élevé - La Réunion (Océan Indien). Ph.D Thesis, Université de la Réunion, La Réunion, France.

Feeley, M.H., Moore, T.C., Jr., Loutit, T.S., Bryant, W.R., 1990. Sequence stratigraphy of Mississippi Fan related to oxygen isotope sea level index. AAPG Bulletin 74, 407-424.

Flood, R.D., Piper, D.J.W., 1997. Amazon Fan sedimentation; the relationship to equatorial climate change, continental denudation, and sea-level fluctuations. In: Proceedings of the Ocean Drilling Program. College Station, Texas (Ocean Drilling Program). Scientific Results 155, pp. 653-675.

Fretzdorff, S., Paterne, M., Stoffers, P., Ivanova, E., 2000. Explosive activity of the Reunion Island volcanoes through the past 260,000 years as recorded in deep-sea sediments. Bulletin of Volcanology 62, 266-277. 
Garcia, M.O., 1996. Turbidites from slope failure on Hawaiian volcanoes. In:

McGuire, W.J., Jones, A.P., Neuberg, J. (Eds.), Volcano Instability on the Earth and other Planets. Geological Society, London, Special Publications 110, pp. 281-294.

Garcia, M.O., Hull, D.M., 1994. Turbidites from giant Hawaiian landslides: Results from Ocean Drilling Program Site 842. Geology 22, 159-162.

Gillot, P.-Y., Nativel, P., 1982. K-Ar chronology of the ultimate activity of Piton des Neiges volcano, Reunion Island, Indian Ocean. Journal of Volcanology and Geothermal Research 13, 131-146.

Gillot, P.-Y., Nativel, P., 1989. Eruptive history of the Piton de la Fournaise volcano, Reunion Island, Indian Ocean. Journal of Volcanology and Geothermal Research 36, 53-65.

Gonfiantini, R., 1984. Advisory Group Meeting on Stable Isotope, Reference Samples for Geochemical and Hydrological Investigations: IAEA, Vienna, 19-21 September 1983: Report to the Director General. International Atomic Energy Agency.

Haurie, J.L., 1987. Géodynamique des cirques de la Réunion : implications géotechniques et stabilité des versants. Ph.D Thesis, Université Scientifique et Médicale de Grenoble, Grenoble, France.

Hunt, J.E., Talling, P.J., Clare, M.A., Jarvis, I., Wynn, R.B., 2015. Long-term (17 Ma) turbidite record of the timing and frequency of large flank collapses of the Canary Islands. Geochemistry, Geophysics, Geosystems 15, 3322-3345, doi: 10.1002/2014GC005232.Hunt, J.E., Wynn, R.B., Talling, P.J., Masson, D.G., 2013. Turbidite record of frequency and source of large volume (>100 $\mathrm{km}^{3}$ ) Canary Island landslides in the last 1.5 Ma: Implications for landslide 
triggers and geohazards. Geochemistry, Geophysics, Geosystems 14, 21002123, doi : 10.1002/ggge.20139.

Ito, M., Masuda, F., 1988. Late Cenozoic deep-sea to fan-delta sedimentation in an arc-arc collision zone, central Honshu, Japan; sedimentary response to varying plate-tectonic regime. In: Nemec, W., Steel, R.J. (Eds.), Fan deltas; sedimentology and tectonic settings. Blackie and Son, Glasgow, UK, pp. 400418.

Iverson, R.M. 1997. The physics of debris flows. Reviews of Geophyics 35, 245-296, doi: 10.1029/97RG00426.

Iverson, R.M., Denlinger, R.P., 2001. Flow of variably fluidized granular masses across three-dimensional terrain: 1 . Coulomb mixture theory, Journal of Geophysical Research 106, 537-552, doi: 10.1029/2000JB900329.

Johannessen, E.P., Steel, R.J., 2005. Clinoforms and their exploration significance for deepwater sands. Basin Research 17, 521-550.

Join, J.-L., 1991. Caractérisation hydrogéologique du milieu volcanique insulaire.

Piton des neiges, île de la Réunion. Ph.D Thesis, Université de Montpellier 2, Montpellier, France.

Khripounoff, A., Vangriesheim, A., Babonneau, N., Crassous, P., Dennielou, B., Savoye, B., 2003. Direct observation of intense turbidity current activity in the Zaire submarine valley at $4000 \mathrm{~m}$ water depth. Marine Geology 194, 151-158. Kluska, J.-M., 1997. Evolution magmatique et morphostructurale du Piton des Neiges au cours des derniers 500000 ans. Ph.D Thesis, Université de Paris Orsay, Paris, France. 
Kokelaar, P., Romagnoli, C., 1995. Sector collapse, sedimentation and clastpopulation evolution at an active island-arc volcano: Stromboli, Italy. Bulletin of Volcanology 57, 240-262.

Krastel, S., Schmincke, H.-U., Jacobs, C.L., 2001. Formation of submarine canyons on the flanks of the Canary Islands. Geo-Marine Letters 20, 160-167.

Le Friant, A., Lebas, E., Clément, V., Boudon, G., Deplus, C., Voogd, B. de, Bachèlery, P., 2011. A new model for the evolution of La Réunion volcanic complex from complete marine geophysical surveys. Geophysical Research Letters, 38, 6 PP, doi:10.1029/2011GL047489.

Lebas, E., Le Friant, A., Boudon, G.,Watt, S.F.L., Talling, P.J., Feuillet, N., Deplus, C., Berndt, C., Vardy, M.E., 2011. Multiple widespread landslides during the long-term evolution of a volcanic island: Insights from high-resolution seismic data, Montserrat, Lesser Antilles. Geochemistry Geophysics Geosystems 12, 20 PP, doi:10.1029/2010GC003451.

Lee, H.J., Syvitski, J.P.., Parker, G., Orange, D., Locat, J., Hutton, E.W.., Imran, J., 2002. Distinguishing sediment waves from slope failure deposits: field examples, including the "Humboldt slide", and modelling results. Marine Geology 192, 79-104.

Lénat, J.F., Labazuy, P., 1990. Morphologies et structures sous-marines de la Reunion. In: Lénat, J.F. (Ed.), Le volcanisme de la Reunion. Monographie, Centre de Recherches Volcanologiques, Clermont-Ferrand. France, pp. 4374.

Lénat, J.-F., Bachèlery, P., Merle, O., 2012. Anatomy of Piton de la Fournaise volcano (La Réunion, Indian Ocean). Bulletin of Volcanology 74, 1945-1961. 
Lénat, J.-F., Boivin, P., Deniel, C., Gillot, P.-Y., Bachèlery, P., 2009a. Age and nature of deposits on the submarine flanks of Piton de la Fournaise (Reunion Island). Journal of Volcanology and Geothermal Research 184, 199-207.

Lénat, J.-F., Merle, O., Lespagnol, L., 2009b. La Réunion: an example of channelled hot spot plume. Journal of Volcanology and Geothermal Research 184, 1-13.

Lénat, J.-F., Gibert-Malengreau, B., Galdéano, A., 2001. A new model for the evolution of the volcanic island of Réunion (Indian Ocean). Journal of Geophysical Research 106, 8645-8663.

Lénat, J.-F., Vincent, P., Bachélery, P., 1989. The off-shore continuation of an active basaltic volcano: Piton de la Fournaise (Réunion Island, Indian Ocean); structural and geomorphological interpretation from sea beam mapping. Journal of Volcanology and Geothermal Research 36, 1-36.

Louvat, P., Allègre, C.J., 1997. Present denudation rates on the island of Réunion determined by river geochemistry: Basalt weathering and mass budget between chemical and mechanical erosions. Geochimica et Cosmochimica Acta $61,3645-3669$.

Manley, P.L., Flood, R.D., 1988. Cyclic Sediment Deposition Within Amazon DeepSea Fan. AAPG Bulletin 72, 912-925.

McDougall, I., 1971. The geochronology and evolution of the young volcanic island of Réunion, Indian Ocean. Geochimica et Cosmochimica Acta 35, 261-288.

Merle, O., Mairine, P., Michon, L., Bachèlery, P., Smietana, M., 2010. Calderas, landslides and paleo-canyons on Piton de la Fournaise volcano (La Réunion Island, Indian Ocean). Journal of Volcanology and Geothermal Research 189, $131-142$. 
Mitchell, N.C., Dade, W.B., Masson, D.G., 2003. Erosion of the submarine flanks of the Canary Islands. Journal of Geophysical Research: Earth Surface 108, doi:10.1029/2002JF000003.

Moore, J.G., Normark, W.R., Holcomb, R.T., 1994. Giant Hawaiian Landslides. Annual Review of Earth and Planetary Sciences 22, 119-144.

Mutti, E., 1985. Turbidite systems and their relations to depositional sequences. In: Zuffa, G.G. (Ed.), Provenance of arenites. NATO, Advanced Scientific Institute, Dordrecht, Holland. Mathematical and Physical Sciences 148, pp. 65-93.

Nativel, P., 1978. Volcans de la Réunion, pétrologie, faciès zéolites, sublimés. Ph. D Thesis, Université Paris Sud, Paris, France.

Normark, W.R., Hess, G.R., Stow, D.A.V., Bowen, A.J., 1980. Sediment waves on the monterey fan levee: A preliminary physical interpretation. Marine Geology $37,1-18$.

Oehler, J.-F., Labazuy, P., Lénat, J.-F., 2004. Recurrence of major flank landslides during the last 2-Ma-history of Reunion Island. Bulletin of Volcanology 66, $585-598$.

Oehler, J.-F., Lénat, J.-F., Labazuy, P., 2008. Growth and collapse of the Reunion Island volcanoes. Bulletin of Volcanology 70, 717-742.

Ollier, G., Cochonat, P., Lénat, J.-F., Labazuy, P., 1998. Deep-sea volcaniclastic sedimentary systems: an example from La Fournaise volcano, Réunion Island, Indian Ocean. Sedimentology 45, 293-330.

Parrenin, F., Barnola, J.-M., Beer, J., Blunier, T., Castellano, E., Chappellaz, J., Dreyfus, G., Fischer, H., Fujita, S., Jouzel, J., Kawamura, K., Lemieux-Dudon, B., Loulergue, L., Masson-Delmotte, V., Narcisi, B., Petit, J.-R., Raisbeck, G., 
Raynaud, D., Ruth, U., Schwander, J., Severi, M., Spahni, R., Steffensen, J.P., Svensson, A., Udisti, R., Waelbroeck, C., Wolff, E., 2007. The EDC3 chronology for the EPICA Dome C ice core. Climate of the Past 3, 485-497. Piper, D.J.W., Normark, W.R., 2001. Sandy fans; from Amazon to Hueneme and beyond. American Association of Petroleum Geologists Bulletin 85, $1407-$ 1438.

Pirmez, C., Flood, R.D., 1995. Morphology and structure of Amazon Channel. In: Proceedings of the Ocean Drilling Program. College Station, Texas (Ocean Drilling Program), Initial Reports 155, pp. 23-45.

Popescu, I., Lericolais, G., Panin, N., Wong, H.., Droz, L., 2001. Late Quaternary channel avulsions on the Danube deep-sea fan, Black Sea. Marine Geology 179, 25-37.

Posamentier, H.W., Vail, P.R., 1988._Eustatic controls on clastic deposition; II, Sequence and systems tract models. In: Wilgus, C.K., Hastings, B.S., Kendall, C.G.S.C., Posamentier, H.W., Ross C.A., Van Wagoner J.C. (Eds.), Sea-level changes; an integrated approach. Society for Sedimentary Geology (SEPM), Special Publication 42, pp. 125-154.

Pudasaini, S.P., 2014. Dynamics of submarine debris flow and tsunami. Acta Mechanica 225, 2423-2434, doi: 10.1007/s00707-014-1126-0.

Pudasaini, S.P., Krautblatter, M., 2014. A two-phase mechanical model for rock-ice avalanches. Journal of Geophysical Research 119, 2272-2290, doi: 10.1002/2014JF003183

Pudasaini, S.P., Wang, Y., Hutter, K., 2005. Modelling debris flows down general channels. Natural Hazards and Earth System Sciences 5, 799-819. 
Quidelleur, X., Holt, J.W., Salvany, T., Bouquerel, H., 2010. New K-Ar ages from La Montagne massif, Réunion Island (Indian Ocean), supporting two geomagnetic events in the time period 2.2-2.0 Ma. Geophysical Journal International 182, 699-710.

Rad, S.D., Allègre, C.J., Louvat, P., 2007. Hidden erosion on volcanic islands. Earth and Planetary Science Letters 262, 109-124.

Reading, H. G., Richards, M., 1994. Turbidite systems in deep-water basin margins classified by grain size and feeder system. AAPG Bulletin 78, 792-822.

Robert, R., 2001. Pluviométrie à l'île de la Réunion : des travaux de J. Defos du Rau (1960) à nos jours. L'Information géographique 1, 53-59.

Rocher, P., 1988a. Contexte volcanique et structural de l'hydrothermalisme récent dans le massif du Piton des Neiges (lle de la Réunion). Etude détaillée du cirque de Salazie. Ph.D Thesis, Université de Paris Orsay, Paris, France.

Rocher, P., 1988b. Nouveau schéma d'évolution volcano-structurale du massif du Piton des Neiges (lle de La Réunion). Géologie de la France 2, 157-162. Rocher, P., 1990. Evolution structurale du massif du Piton des Neiges. In: Lénat, J.F. (Ed.), Le volcanisme de la Réunion-Monographie. Centre de Recherche en Volcanologie, Clermont-Ferrand, France, pp. 145-161.

Romagnoli, C., Casalbore, D., Bosman, A., Braga, R., Chiocci, F.L., 2013. Submarine structure of Vulcano volcano (Aeolian Islands) revealed by high-resolution bathymetry and seismo-acoustic data. Marine Geology 338, 30-45, doi: 10.1016/j.margeo.2012.12.002.

Romagnoli, C., Kokelaar, P., Casalbore, D., Chiocci, F.L., 2009. Lateral collapses and active sedimentary processes on the northwestern flank of Stromboli volcano, Italy. Marine Geology 265, 101-119. 
Saint-Ange, F., 2009. La sédimentation volcaniclastique en contexte de point chaud (île de La Reunion, Océan Indien). Ph.D Thesis, Université de La Réunion, La Réunion, France.

Saint-Ange, F., Bachèlery, P., Babonneau, N., Michon, L., Jorry, S.J., 2013.

Volcaniclastic sedimentation on the submarine slopes of a basaltic hotspot volcano: Piton de la Fournaise volcano (La Réunion Island, Indian Ocean). Marine Geology 337, 35-52.

Saint-Ange, F., Savoye, B., Michon, L., Bachelery, P., Deplus, C., Voogd, B.D., Dyment, J., Drezen, E.L., Voisset, M., Friant, A.L., Boudon, G., 2011. A volcaniclastic deep-sea fan off La Réunion Island (Indian Ocean): Gradualism versus catastrophism. Geology 39, 271-274.

Salvany, T., Lahitte, P., Nativel, P., Gillot, P.-Y., 2012. Geomorphic evolution of the Piton des Neiges volcano (Réunion Island, Indian Ocean): Competition between volcanic construction and erosion since 1.4 Ma. Geomorphology 136, $132-147$.

Schmincke, H-U., Sumita, M., 1998. Volcanic evolution of Gran Canaria reconstructed from apron sediments: synthesis of VICAP project drilling. In: Weaver, P.P.E, Schmincke, H.-U., Firth, J.V., Duffield, W. (Eds.), Proceedings of the Ocean Drilling Program, Scientific Results 157, pp. 443-469.

Sisavath, E., 2011. Processus de transfert des éléments volcanodétritiques dans les plaines abyssales autour de l'lle de La Réunion (Océan Indien) : Exemple du système turbiditique de Cilaos. Ph.D Thesis, Université de La Réunion, La Réunion, France.

Sisavath, E., Mazuel, A., Jorry, S.J., Babonneau, N., Bachèlery, P., de Voogd, B., Salpin, M., Emmanuel, L., Beaufort, L., Toucanne, S., 2012. Processes 
controlling a volcaniclastic turbidite system during the last climatic cycle:

Example of the Cilaos deep-sea fan, offshore La Réunion Island. Sedimentary Geology, 281, 180-193.

Sisavath, E., Babonneau, N., Saint-Ange, F., Bachèlery, P., Jorry, S.J., Deplus, C., De Voogd, B., Savoye, B., 2011. Morphology and sedimentary architecture of a modern volcaniclastic turbidite system: The Cilaos fan, offshore La Réunion Island. Marine Geology 288, 1-17.

Smietana, M., 2011. Pétrologie, géochronologie (K-Ar) et géochimie élémentaire et isotopique ( $\mathrm{Sr}, \mathrm{Nd}, \mathrm{Hf}, \mathrm{Pb})$ de laves anciennes de la Réunion : Implications sur la construction de l'édifice volcanique. Ph.D Thesis, Université de la Réunion, La Réunion, France.

Stow, D.A.V., Howell, D.G., Nelson, D.H., 1984. Sedimentary, tectonic, and sea level controls on submarine fan and slope-apron turbidite systems. Geo-Marine Letters 3, 57-64.

Stuiver, M., Reimer, P.J., 1993. Extended ${ }^{14} \mathrm{C}$ data base and revised CALIB $3.0{ }^{14} \mathrm{C}$ age calibration program. Radiocarbon 35, 215-230.

Unterseh, S., 1999. Cartographie et Caractérisation du Fond Marin par Sondeurs Multifaisceaux. Ph.D Thesis, École Nationale Supérieure de Géologie de Nancy, Nancy, France.

Verschuren, D., Damsté, J.S.S., Moernaut, J., Kristen, I., Blaauw, M., Fagot, M., Haug, G.H., 2009. Half-precessional dynamics of monsoon rainfall near the East African Equator. Nature 462, 637-641.

Vail, P.R., Audemard, F., Bowman, S.A., Eisner, P.N., Perez-Cruz, G., 1991. The stratigraphic signatures of tectonics, eustasy and sedimentation - An overview. 
In: Einsele, G., Ricken, W., Seilacher, A. (Eds.), Cyclic stratigraphy II. Springer-Verlag, New York, pp. 617-659.

Weber, M.E., Wiedicke, M.H., Kudrass, H.R., Huebscher, C., Erlenkeuser, H., 1997. Active growth of the Bengal Fan during sea-level rise and highstand. Geology 25, 315-318.

Weimer, P., 1990. Sequence stratigraphy facies geometrics, and depositional history of the Mississippi Fan, Gulf of Mexico. American Association of Petroleum Geologists Bulletin 74, 425-453.

Weaver, P.P.E., Wynn, R.B., Kenyon, N.H., Evans, J., 2000. Continental margin sedimentation, with special reference to the north-east Atlantic margin. Sedimentology 47, pp. 239-356

Wynn, R.B., Stow, D.A.V., 2002. Classification and characterisation of deep-water sediment waves. Marine Geology 192, 7-22.

Wynn, R.B., Piper, D.J., Gee, M.J., 2002. Generation and migration of coarsegrained sediment waves in turbidity current channels and channel-lobe transition zones. Marine Geology 192, 59-78.

\section{List of tables}

Table 1. List of piston cores collected along the Mafate turbidite system.

Table 2. Radiocarbon dates obtained in KERO-07, KERO-20 and MD11-3342.

\section{List of figures}

Fig. 1. Location map of La Réunion Island and the volcanic edifices built by La Réunion hotspot activity. ETOPO1 shaded bathymetric and topographic background. 
Fig. 2. (a) Acoustic backscatter map of the seafloor around La Réunion Island, compiled from FOREVER and ERODER surveys, and location of the five turbidite systems: (1) Mafate, (2) Saint-Denis, (3) Salazie, (4) Saint-Joseph, (5) Cilaos. The dotted lines indicate the Mahanoro-Wilshlaw and Mauritius fracture zones. The white line corresponds to the $-4000 \mathrm{~m}$ isobath. (b) Closer view of the island. Onland are located the three "cirques" of Mafate (a), Salazie (b) and Cilaos (c) and the main rivers draining their watersheds. The dotted line separates the Piton des Neiges volcano (NW) and the Piton de la Fournaise volcano (SE).

Fig. 3. Shaded relief bathymetric map compiled from FOREVER and ERODER oceanic surveys and the SHOM dataset for the shallow water sector (resolution $100 \mathrm{~m}$ ), and interpretation of the main morphological features of the Mafate and Saint-Denis sedimentary systems. The thick black lines represent the overall extension on the Mafate turbidite complex. On land, blue outlines and numbers correspond to the main watersheds: (1) "cirque" of Mafate and Rivière des Galets, (2) Rivière Saint-Denis, (3) Rivière des Pluies. The hatched area corresponds to de "Rivière des Galets" delta. The canyons that feed the turbidite complex are identified by letters from "a" to "e". Ship tracks: FOREVER cruise (yellow line), ERODER 1 cruise (green line) and ERODER 2 cruise (red line). Red dots represent KERO-07, KERO-20 and MD11-3342 cores sampled during the FOREVER and ERODER cruises and S17-666 core sampled during SO-87 cruise (after Fretzdorff et al., 2000). Black boxes "A" and "C" correspond to the location of the detailed morphological map presented in the Fig. 4. 
Fig. 4. Detailed slope gradient maps of the Mafate turbidite complex and their interpretation, compiled from FOREVER and ERODER oceanic surveys and the SHOM dataset for the shallow water sector (resolution $100 \mathrm{~m}$ ). The data are shown with high slopes in black. The locations of the three zones shown in Fig. 3: (a) Shallow water sector, canyons heads of the Mafate and Saint-Denis turbidite systems. (b) Mafate canyon deflection and adjacent landslide deposits. (c) Channels and erosional features along the Mafate turbidite system. On the right are presented the two bathymetric profiles crossing the channels and dunes. The main watersheds and canyons are respectively identified by numbers from "1" to " 3 " and letters from "a" to "e" as in Fig. 3. The hatched area corresponds to de "Rivière des Galets" delta.

Fig. 5. (a) Schematic map of main areas of the Mafate and Saint-Denis turbidite systems and location of slope profiles. (b) Mafate (in black), Saint-Denis (in grey) and connection area (in red) slope profiles and gradients. The canyons that feed the turbidite complex are identified by letters from "a" to "e" as in Figs. 4,5 .

Fig. 6. (a) Backscatter map of the Mafate turbidite complex, compiled from FOREVER and ERODER 1 \& 2 surveys. (b) Interpreted geomorphological map representing the superficial architecture of the Mafate and Saint Denis turbidite systems. The division of canyons, channels, sediment waves and submarine landslide in sub-units highlights the contrasts in surface sediment distribution with darker tones associated to coarser material (high reflectivity) and lighter tones to finer material (low-reflectivity). The two seismic profiles crossing the Mafate and Saint-Denis turbidite systems are represented by the numbered black lines, the numbers corresponding to the shot points. Black 
boxes correspond to the location of the TOBI images presented in the Fig. 8 . On land, blue outlines correspond to the main watersheds named in Fig. 3.

Fig. 7. Detailed sedimentary features imaged by the TOBI side-scan sonar superimposed onto the EM120 backscatter map in the Mafate turbidite complex (the white line being an artifact that marks the limits of the acquisition areas). The data are shown with high backscatter in black. The locations of the three zones shown in Fig. 7b: (a) Braided channels, sandy-bars and erosional features along the Mafate turbidite system. (b) Mafate canyon deflection and adjacent landslide deposits. (c) "Plume-like" channels along the Saint-Denis turbidite system.

Fig. 8. Interpretation of two seismic profiles crossing the Mafate and Saint-Denis deep-sea fans (locations on Fig. 6b). Profile 21 crosses the median part of the Mafate turbidite system and the distal lobe of the Saint-Denis turbidite system; profile 02 crosses the distal part of the Mafate deep-sea fan. Black boxes correspond to the zoom locations. Black arrows localise the supplying channel that intersects the seismic profile 02 close to the shot 2100 north of the Mafate turbidite system. MWD: mass-wasting deposits.

Fig. 9. Photography, lithological description, grain size variability and $\delta^{18} \mathrm{O}$ measurements (when available) of (a) KERO-07, (b) KERO-20 and (c) MD113342 cores. Black lines correspond to the location of turbidite deposits. Red dots indicate the location of ${ }^{14} \mathrm{C}$ datings and the corresponding ages. Grain sizes range from clay $(\mathrm{C})$, clayey-silt (CS) and silt (S) to very fine (vf), fine (f), medium ( $\mathrm{m}$ ) and coarse (c) sand.

Fig. 10. (a) KERO-07 $\delta^{18} \mathrm{O}$ stratigraphy (black curve) anchored by two ${ }^{14} \mathrm{C}$ dates (black dots), calibrated with the EPICA Dome $\mathrm{C} \delta^{18} \mathrm{O}$ age model (light grey 
curve) (after Parrenin et al., 2007) and S17-666 $\delta^{18} \mathrm{O}$ record (dark grey curve) (after Fretzdorff et al., 2000) for the last 25 ka. (b) KERO-07 (black) and KERO-20 (grey) Ca XRF curves for the last $25 \mathrm{ka}$ and ${ }^{14} \mathrm{C}$ datings (black dots).

Fig. 11. Sedimentation rates observed in hemipelagic sediments for cores KERO 07 (black line) and KERO 20 (grey line) for the last $25 \mathrm{ka}$.

Fig. 12. (a) Relative sea-level curve and meltwater pulses (MWP) (from Alley et al., 2005) and BIT index records (green line) of Lake Challa in equatorial East Africa (from Verschuren et al., 2009) for the last $25 \mathrm{ka}$. (b) Number of turbidites per 1 ky recorded in KERO-07 (blue) and KERO-20 (red). 
Table 1.

\begin{tabular}{|c|c|c|c|c|c|c|}
\hline Name & Type & Latitude & Longitude & $\begin{array}{c}\text { Depth } \\
(\mathrm{m})\end{array}$ & $\begin{array}{l}\text { Length } \\
\text { (cm) }\end{array}$ & Location \\
\hline KER0-07 & $\begin{array}{l}\text { Küllenberg } \\
\text { Piston core }\end{array}$ & $20^{\circ} 53.59 \mathrm{~S}$ & $5^{\circ} 12.19 \mathrm{E}$ & -791 & & $\begin{array}{l}\text { Terrace close to the Mafate } \\
\text { canyon head }\end{array}$ \\
\hline KERO-20 & $\begin{array}{l}\text { Küllenberg } \\
\text { Piston core }\end{array}$ & $20^{\circ} 16.68 \mathrm{~S}$ & $54^{\circ} 54.45 \mathrm{E}$ & -4317 & & $\begin{array}{l}\text { Mafate distal area, western } \\
\text { sediment wave field }\end{array}$ \\
\hline MD11-3342 & $\begin{array}{l}\text { Calypso } \\
\text { Piston core }\end{array}$ & $20^{\circ} 19.96 \mathrm{~S}$ & $54{ }^{\circ} 34.76 \mathrm{E}$ & & & Abyssal plain \\
\hline
\end{tabular}


Table 2.

\begin{tabular}{lccccc}
\hline Lab code & Core & $\begin{array}{c}\text { Depth } \\
\text { (cm bsl) }\end{array}$ & $\begin{array}{c}\text { AMS }{ }^{14} \mathbf{C} \\
\text { age (yr) }\end{array}$ & $\begin{array}{c}\text { AMS }{ }^{14} \mathbf{C} \\
\text { age }(-400 \text { yr) }\end{array}$ & $\begin{array}{c}\text { Calendar age } \\
\text { (cal yr BP) }\end{array}$ \\
\hline SacA 24239 & KERO-07 & 229 & $8755 \pm 40$ & 8355 & $9436 \pm 40$ \\
SacA 21880 & KERO-07 & 274 & $16110 \pm 50$ & 15710 & $18834 \pm 50$ \\
SacA 29352 & KERO-20 & 473 & $18440 \pm 100$ & 18040 & $21507 \pm 100$ \\
SacA 26339 & MD11-3342 & 75 & $9170 \pm 45$ & 8770 & $9979 \pm 45$ \\
SacA 27554 & MD11-3342 & 150 & $12650 \pm 50$ & 12250 & $14106 \pm 50$
\end{tabular}




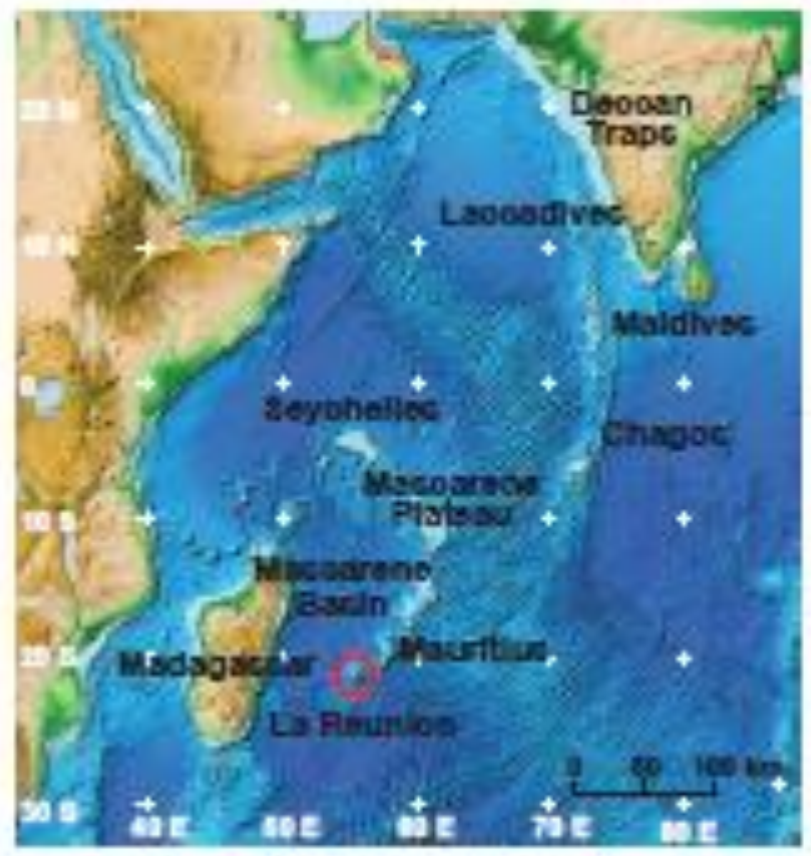

Figure 1

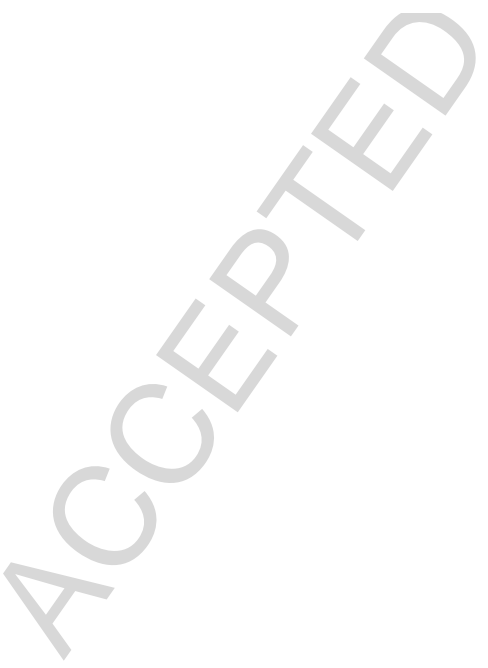



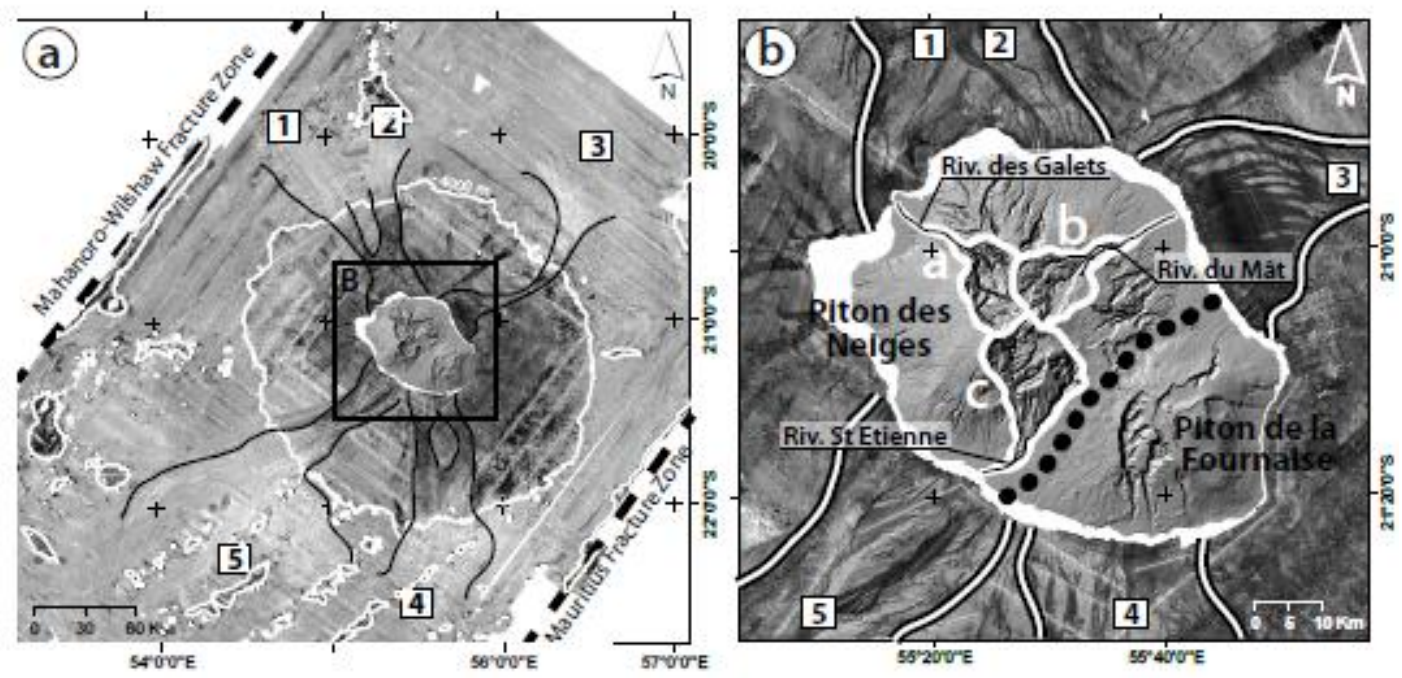

Figure 2 


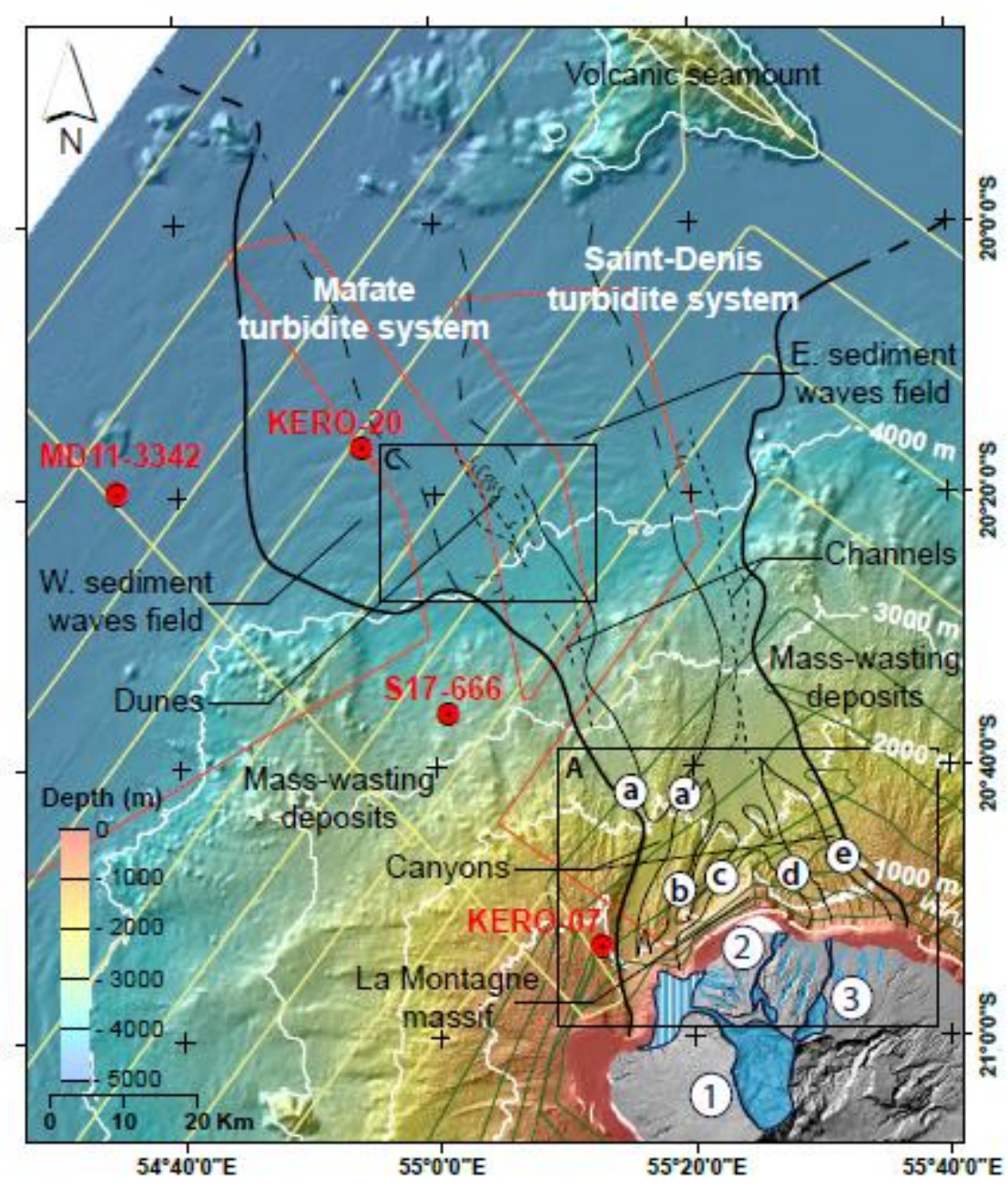

Figure 3 


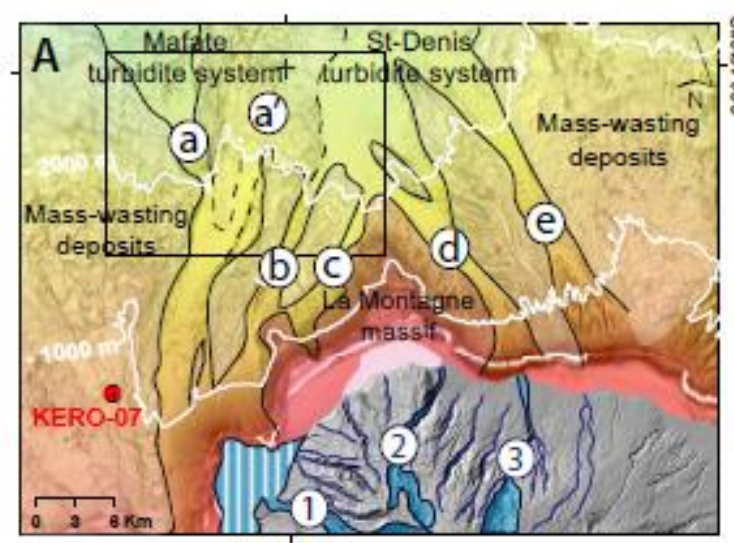

$55^{\circ} 20^{\prime} 0^{\circ} \mathrm{E}$

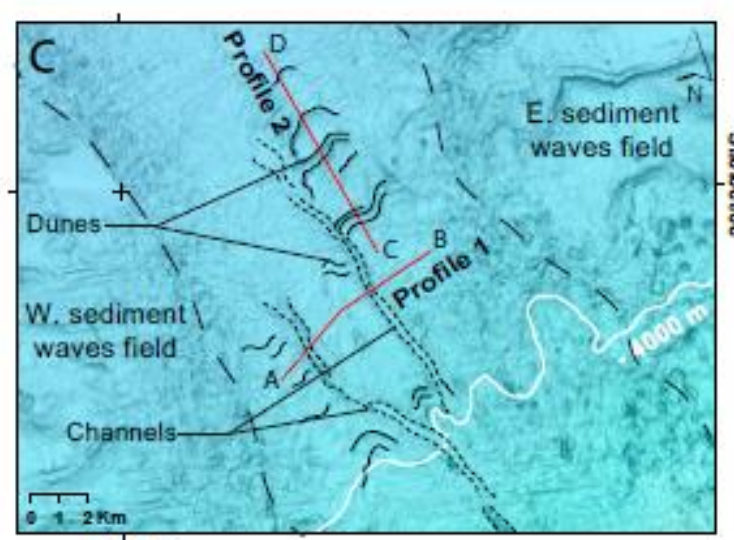

$55^{\circ} 0^{\circ} 0^{\circ E}$

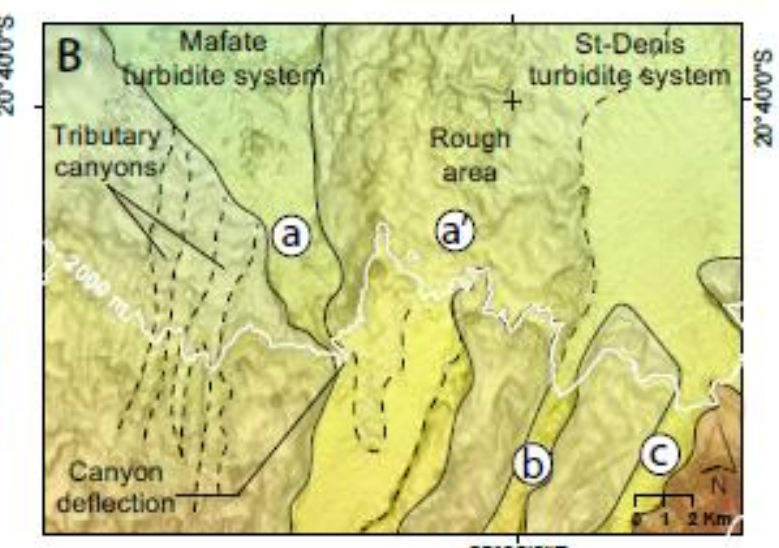

$55^{\circ} 20^{\circ} 0^{\circ} \mathrm{E}$
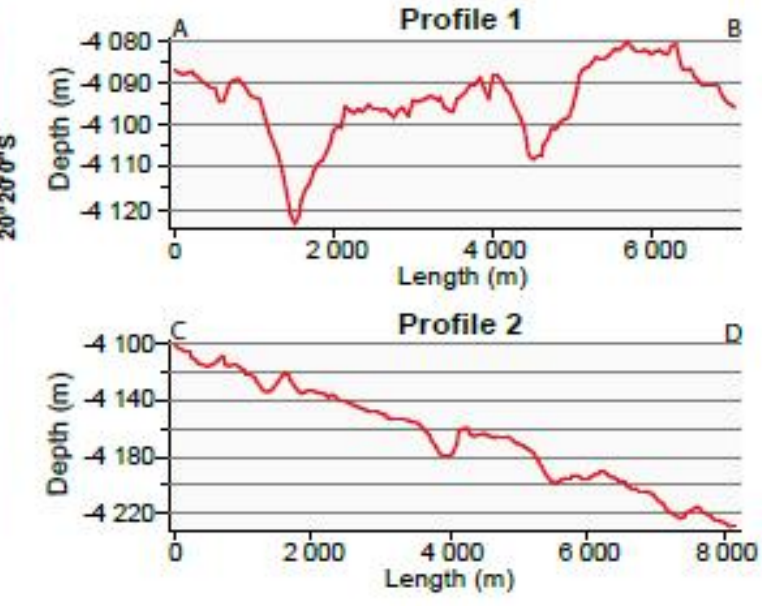

Figure 4 


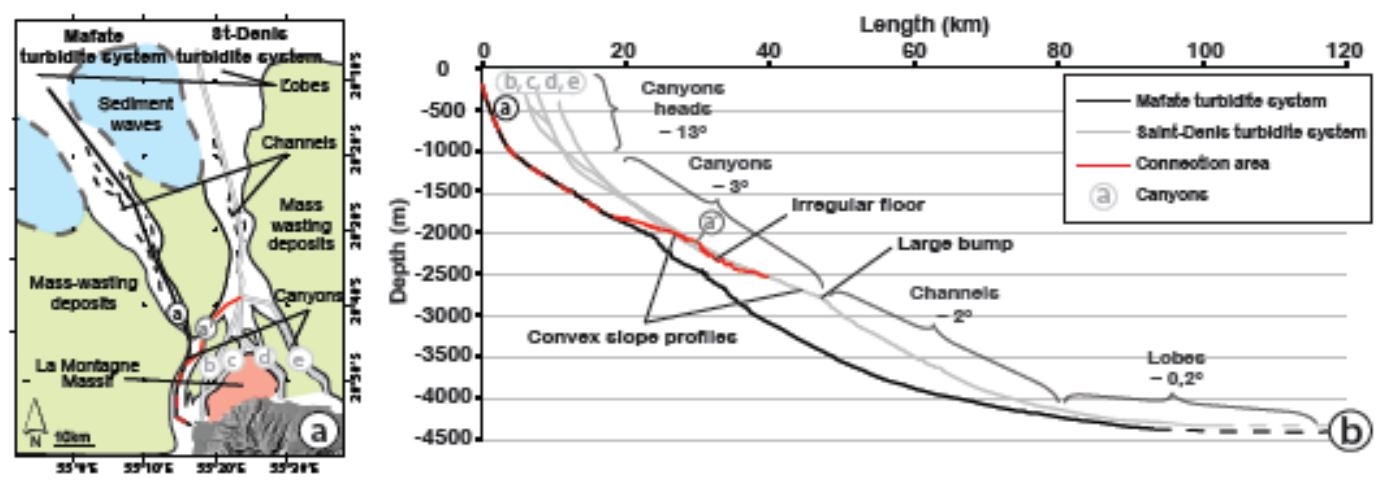

Figure 5 

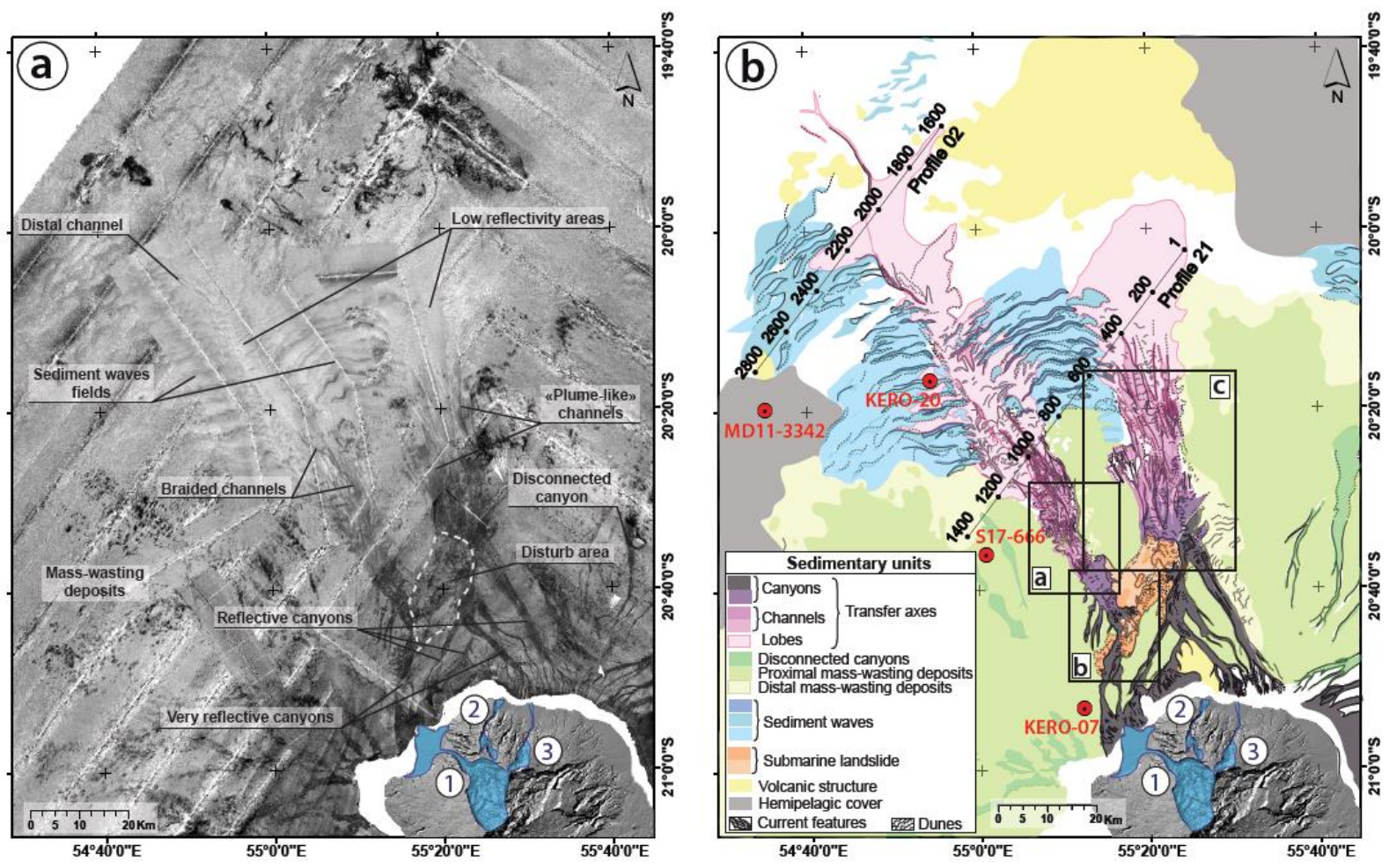

Figure 6 

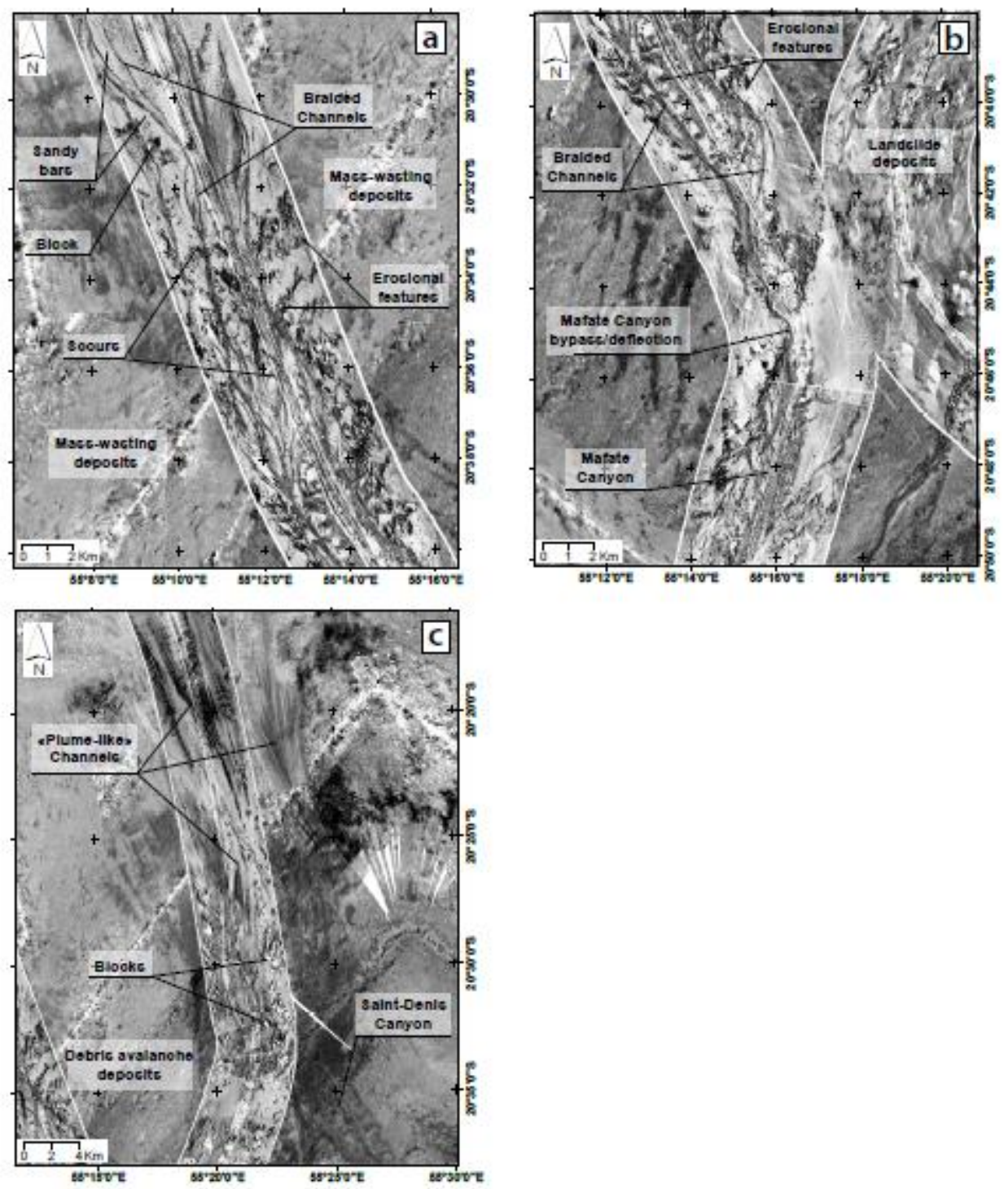

Figure 7 

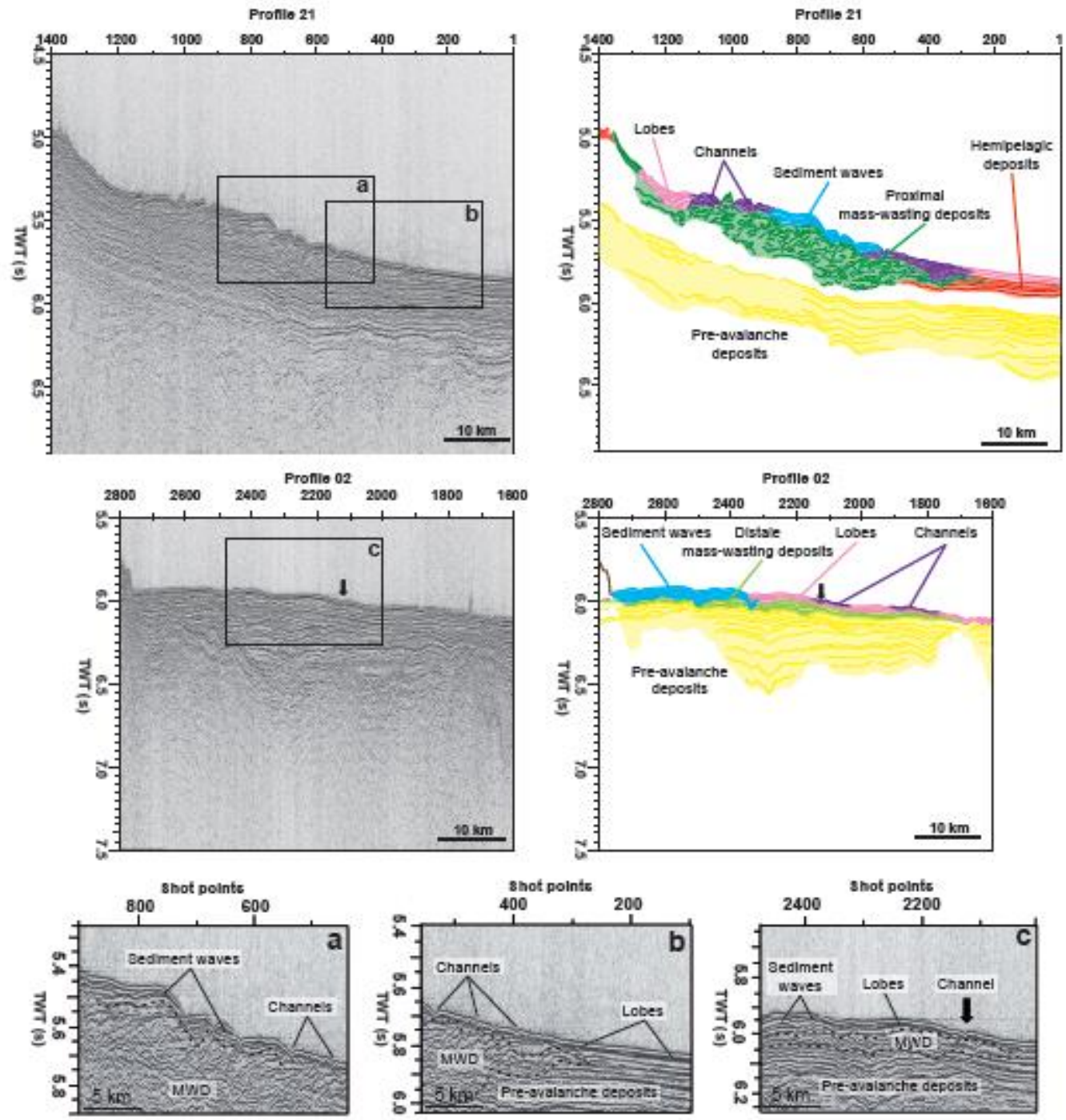

Figure 8 

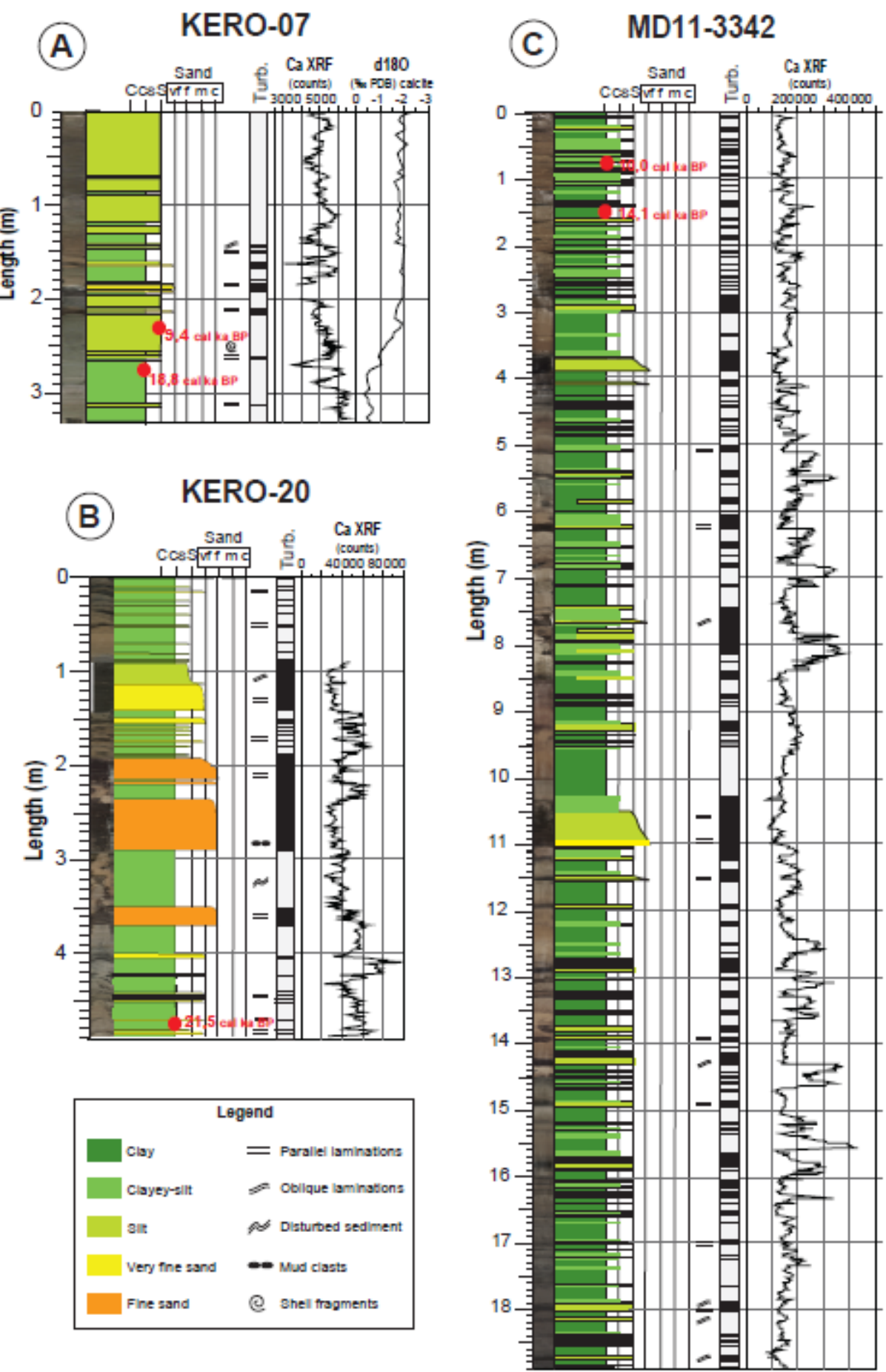

Figure 9 


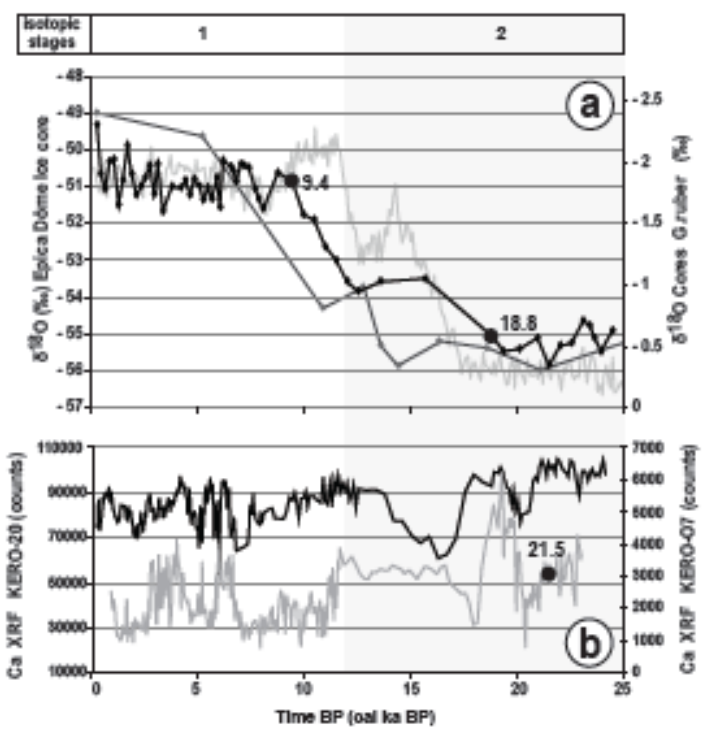

Figure 10 
Sedimentation rates (cm/ka)

In hemipelagic sediments

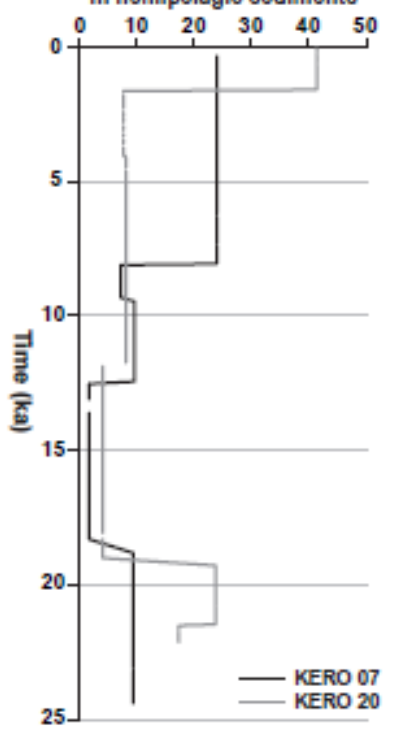

Figure 11 


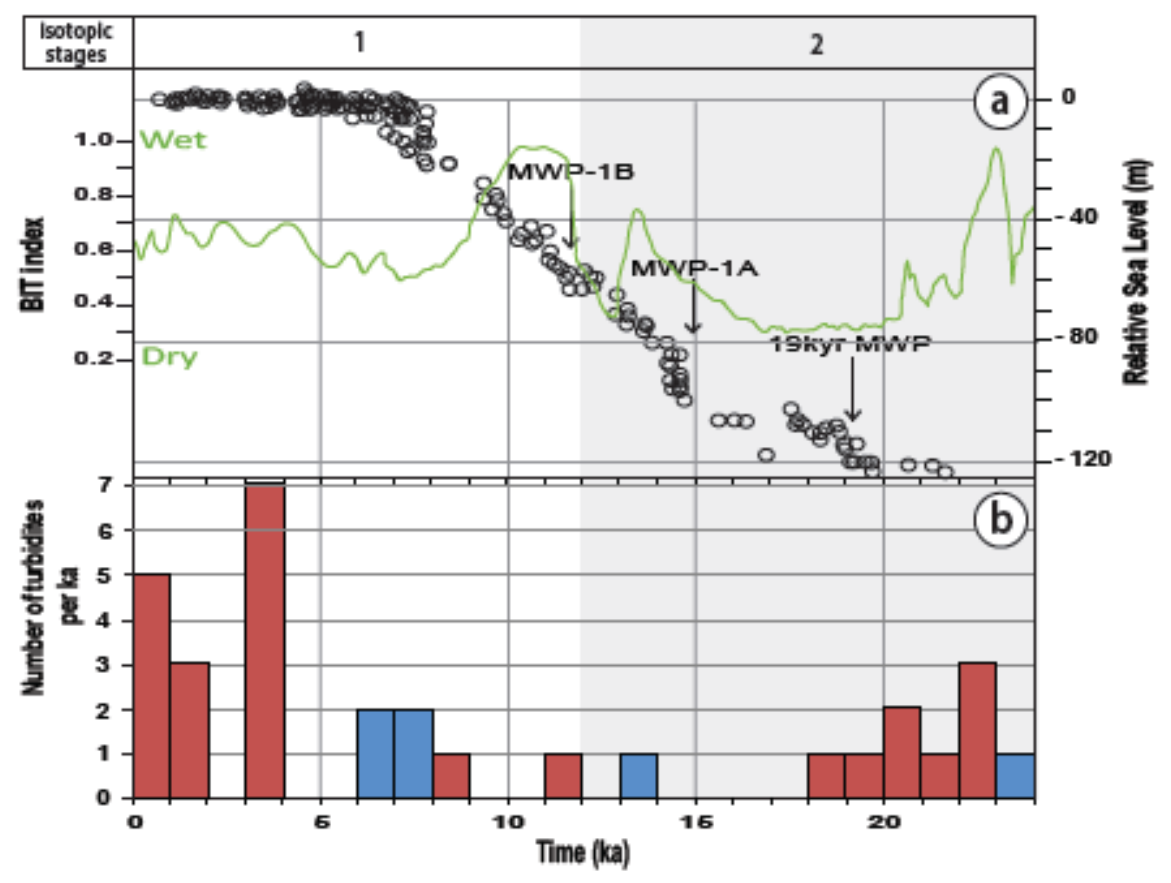

Figure 12 